\title{
Spatial management of the European hake Merluccius merluccius fishery in the Catalan Mediterranean: Simulation of management alternatives with the InVEST model
}

\author{
Meryeme Khoukh ${ }^{1}$, Francesc Maynou ${ }^{2}$ \\ ${ }^{1}$ Institut Agronomique et Vétérinaire Hassan II, Madinat Al Irfane, B.P. 6202 Rabat, Morocco. \\ (MK) (Corresponding author) E-mail: khoukh.meryeme@ gmail.com. ORCID iD: https://orcid.org/0000-0003-4949-9845 \\ ${ }^{2}$ Institut de Ciències del Mar, CSIC, Pg. Marítim de la Barceloneta 37-49, 08003 Barcelona, Spain. \\ (FM) E-mail: maynouf@icm.csic.es. ORCID iD: https://orcid.org/0000-0001-7200-6485
}

\begin{abstract}
Summary: European hake (Merluccius merluccius) is an important commercial fisheries species that shows growth overfishing, with catches basically focused on juveniles. This study assesses the benefit of closing a coastal area (an essential habitat for European hake recruits) to fishing, in addition to other alternatives of spatial management, compared with traditional, non-spatial management scenarios on fishing grounds exploited by the bottom trawl fleets of Blanes and Palamós (Province of Girona, NE Spain). We use InVEST, a spatially explicit model of intermediate complexity that simulates the bioeconomic effects of management measures for decision making. The sensitivity analysis of the model results shows the high influence of some parameters, particularly the parameterization of the recruitment submodel and European hake's fecundity coefficients. The results are also examined in the light of uncertainty on migration parameters: in the two cases analysed (considering migration patterns or not), the results of the indicators (catch and revenues, abundance, recruitment and spawning stock biomass) were qualitatively similar and all show that the application of a restricted fishing area in one particular fishing ground (Vol de Terra) is the best management alternative. Its bioeconomic effects are comparable to a reduction of fishing effort of up to $20 \%$. With high levels of ontogenetic migration, fishing on a second fishing ground (Cul de Rec - El Pas) should be restricted to enhance the biomass of the European hake population.
\end{abstract}

Keywords: Merluccius merluccius; fisheries spatial management; essential habitat; InVEST; nursery habitats; fishing grounds.

Gestión espacial de la pesquería de merluza europea Merluccius merluccius en el Mediterráneo catalán: Simulación de distintas alternativas de gestión mediante el modelo InVEST

Resumen: La merluza europea (Merluccius merluccius) es una especie importante de la pesquería comercial que muestra síntomas de sobreexplotación de crecimiento ya que sus capturas se basan esencialmente en juveniles. En este estudio evaluamos los beneficios de cerrar un área costera a la explotación pesquera (hábitat esencial para los juveniles de merluza europea), así como otras alternativas de gestión espacial, comparadas con escenarios de gestión tradicional sin restricciones espaciales, en los caladeros explotados por las flotas de arrastre de Blanes y Palamós (NE España). El análisis se basa en InVEST, un modelo de complejidad intermedia explícito espacialmente que permite simular los efectos bioeconómicos de las medidas de gestión para la toma de decisiones. El análisis de sensibilidad de los resultados del modelo muestra que la influencia de ciertos parámetros sobre la variabilidad de los resultados es elevada, en particular la parametrización del submodelo de reclutamiento y los coeficientes de fecundidad de la merluza europea. Los resultados se examinan también en función de la incertidumbre de los parámetros de migración: en los dos casos considerados (con o sin migración), los resultados de los distintos indicadores (capturas e ingresos, abundancia, reclutamiento y biomasa frezante) fueron cualitativamente similares y todos coinciden en que el establecimiento de un área restringida a la pesca en un determinado caladero (Vol de Terra) representa la mejor alternativa de gestión. Sus efectos bioeconómicos son comparables a la reducción de un $20 \%$ del esfuerzo de pesca. Con niveles importantes de migración ontogenética, la pesca en un segundo caladero (Cul de Rec - El Pas) debería ser también restringida para incrementar la biomasa de la población de merluza europea.

Palabras clave: Merluccius merluccius; gestión espacial de pesquerías; hábitat esencial; InVEST; zonas de alevinaje; caladeros.

Citation/Cómo citar este artículo: Khoukh M., Maynou F. 2018. Spatial management of the European hake Merluccius merluccius fishery in the Catalan Mediterranean: Simulation of management alternatives with the InVEST model. Sci. Mar. 82S1: 175-188. https://doi.org/10.3989/scimar.04748.18A

Editor: M. Demestre.

Received: January 8, 2018. Accepted: September 3, 2018. Published: October 29, 2018.

Copyright: ( 2018 CSIC. This is an open-access article distributed under the terms of the Creative Commons Attribution 4.0 International (CC BY 4.0) License. 


\section{INTRODUCTION}

European hake [Merluccius merluccius (Linnaeus, 1758)] is one of the most important demersal species of the Mediterranean demersal ecosystem. This species of great commercial value shows growth overfishing, with catches basically focused on juveniles (Recasens et al. 1998, Lleonart et al. 2003). In the Mediterranean Sea, European hake catches have decreased from 52394 $\mathrm{t}$ in 1994 to $20370 \mathrm{t}$ in 2014. In GSA 6, this species requires immediate attention as its stocks show a clear pattern of declining recruitment and a high exploitation rate focused on recruits (age group 0) and age group 1 (STECF 2015).

The protection of European hake spawning areas has been proposed as an effective measure for improving the size composition of catches (Caddy 1999). The implementation of new spatial management measures such as marine protected areas (MPAs) could be the best alternative for the recovery of the fishery and for aligning the exploitation of Mediterranean fisheries resources with the Common Fisheries Policy objectives in terms of fishing mortality levels compatible with the maximum sustainable yield (MSY) in 2020 (Goñi et al. 2004, Maynou 2014). Several studies of European hake populations in the Mediterranean show that the species recruits in stable nursery areas that are recurrent from year to year (Colloca et al. 2015, Fiorentino et al. 2003, Tserpes et al. 2008), and restricting fishing effort in these areas would make an important contribution to reducing fishing mortality for age 0 European hake, thus contributing to stock rebuilding.

Several quantitative models have been developed to support decision making in fisheries management. According to their level of complexity, the fisheries literature has investigated "simple" models such as VIT (Lleonart and Salat 1992) that reflect the traditional vision of fisheries management by considering a single species with fleets that interact technically only, and "complex" models such as ECOPATH (Polovina and Ow 1983, Christensen and Pauly 1992), ECOSIM (Walters et al. 1997) and ECOSPACE (Walters et al. 1999) that try to represent all trophic levels in an ecosystem in a balanced manner. Finally, the literature offers models of intermediate complexity (Plagányi et al. 2014) or minimally realistic models that represent only a subset of (fisheries-relevant) ecosystem processes, with a limited number of species most likely to have important interactions with one species or a group of species of interest. These include the InVEST model (Integrated Valuation of Ecosystem Services and Tradeoffs, Sharp et al. 2016) chosen in this study, and which includes economic aspects in addition to the biological ones.

The InVEST suite of models includes software tools used to map and value natural goods and services that sustain human economies (Sharp et al. 2016). The InVEST toolbox contains ecosystem models designed for freshwater, marine and coastal ecosystems, among which the InVEST fisheries model (Arkema et al. 2015) was selected for our analyses. InVEST focuses on the quantification of trade-offs associated with alternative management strategies (in the context of fisheries, see Smith 1994).

The main objective of this study is to evaluate the biological and economic benefits of closing a shallow area (an essential habitat of European hake recruits) to fishing and the consequences of various spatial management scenarios applied to the European hake fishery in the Catalan sea. The study emphasizes the importance of simulating the bioeconomic effects of such spatial management measures for decision making through the use of a management strategy evaluation (MSE) approach. MSE has been widely recognized as a valuable tool for testing the robustness of management procedures to uncertainties in the fishing system (Kell and Fromentin 2007). MSE can be applied by using simulations to compare the effectiveness of different combinations of management strategies for achieving the expected management objectives and to compare the strength of these strategies with regard to errors and uncertainty (Smith 1994). Here, we assess the trade-off of management strategies based on spatial restrictions compared with effort limitation strategies.

\section{MATERIAL AND METHODS}

\section{Investigated fisheries}

Our study area is located in the Catalan sea (GSA 6), including the area fished by the bottom trawl fleet from the ports of Blanes and Palamós (province of Girona, NE Spain, Fig. 1). In 2015, these two ports registered $27 \%$ of the total catches of European hake landed in Catalonia (1500 t) and are the most important ports in the autonomous community in terms of the operational fishing fleet: $40 \%$ of the operational fishing fleet in Girona (258 vessels) and more than $14 \%$ of the operational fleet in Catalonia (727 vessels).

In the study area, European hake is mainly exploited by bottom trawling, with 45 vessels ( $79 \%$ of the local fleet) with a size between 9 and $28 \mathrm{~m}$ length overall. It is also exploited, but to a lesser extent, by bottom longline, with 12 operational vessels $(21 \%$ of the local fleet) and a ship size of between 6 and 11 $\mathrm{m}$ length overall. The number of fishing vessels has shown a decreasing trend in the last ten years (STECF 2015), as has the trawling effort (number of boats * days at sea), with a marked decline from 2009 to 2010 and from 2014 to 2015 . The same trends have been reported for the Catalan fleet since 2005. The reasons for this decline are not well understood (Irazola et al. 1996), but probably originate from a combination of political measures aimed at limiting fishing effort, the removal of less efficient fishing units, and the general decrease in fisheries profitability in the Mediterranean owing to declining fish stocks.

\section{The InVEST model}

We used the InVEST model (Integrated Valuation of Ecosystem Services and Tradeoffs, https:// www.naturalcapitalproject.org/invest/), developed 


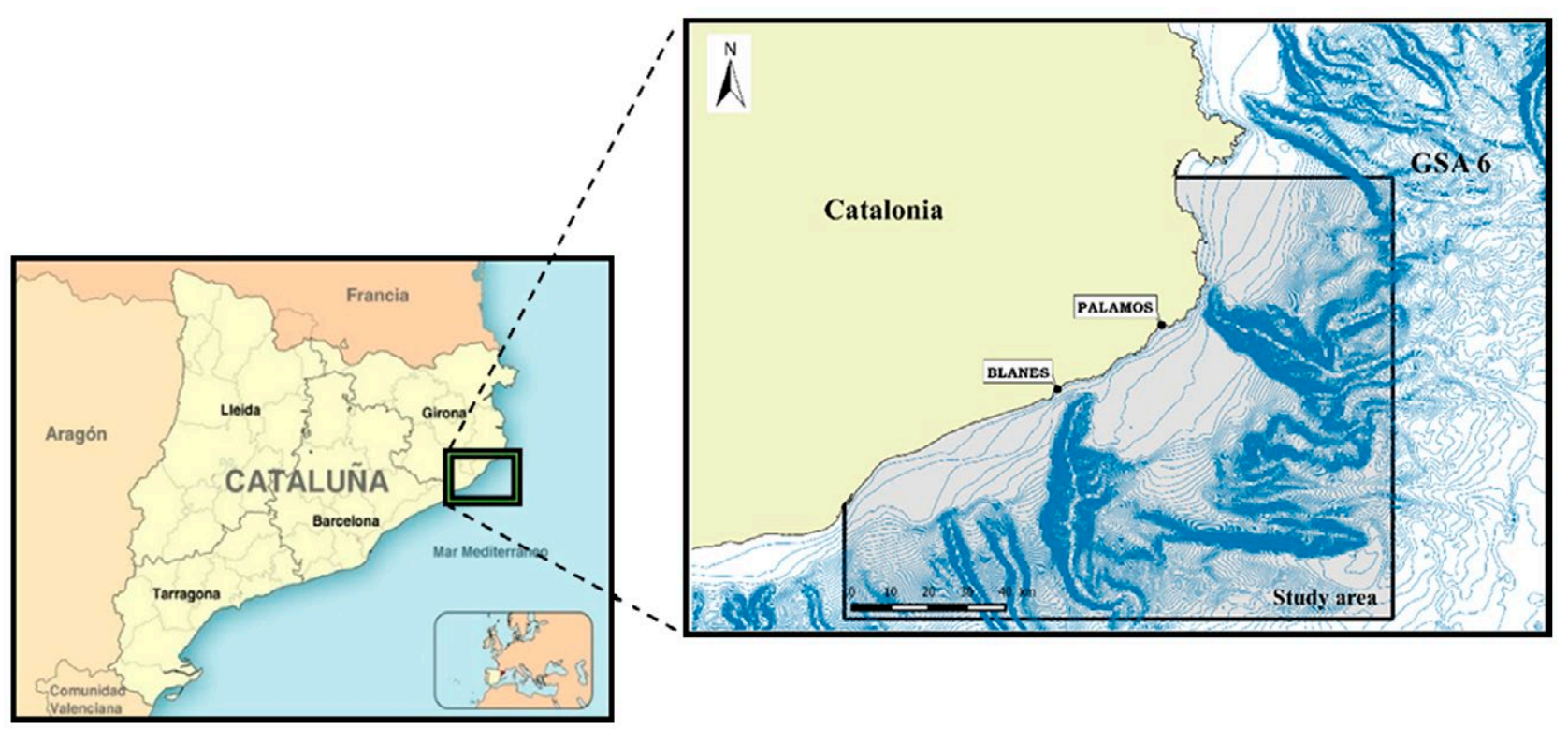

Fig. 1. - Study area.

by the Natural Capital Project (Sharp et al. 2016), which can be used to quantify and map the values of ecosystem services to translate the understanding of the values of nature into management decisions. The software includes 17 models for analysing marine and terrestrial environments, including fish production, aquaculture, habitat quality, coastal protection, water quality and recreational fishing. The InVEST fisheries production model produces estimates of the volume and economic value of catches of the monospecific fisheries. It is a population model structured by age or stage, and it is presented as a generic model that can be adapted to most species and geographies. However, InVEST is not intended to provide an accurate prediction of these estimates, but rather is used as a tool to explore the consequences of decisions that could affect fish production. The particularity of the InVEST model is that it includes both biological and economic aspects. Furthermore, it is spatially explicit, using maps as a source of information and producing maps as outputs. Natural Capital provides software in Python for the execution of simulations. We used InVEST version 3.3.32 and worked with the Windows 10 operating system.

\section{Inputs}

InVEST uses life-history information and survival parameters to estimate the volume and the value of harvests. In the case of a population structured by age, we estimated the parameters of the population that characterize the life history of the species (recruitment, ontogenic migrations, natural mortality, maturity, weight and fertility), the subregions of interest as defined by the fishing grounds within the study area, the attributes of each subregion (fraction of exploitation and larval dispersal), the behaviour of the fishery (vulnerability to fishing), the habitat dependencies (importance and availability of nursery habitat) and optionally, economic valuation (price per unit catch).

\section{Outputs}

The model is executed according to a number of time steps specified by the user and sufficient for the population to reach a state of equilibrium. The results of the model are estimates of the volume of the catch (in t) and economic value of the catches (in $€$ ) in the last step of execution and within the subregions established, in addition to estimates of abundance by age class and subregion in all years of simulation. The results of multiple executions of the model can be compared, each one representing different scenarios of habitat extension, environmental conditions and/ or fishing pressure. The results can be added from the folders to the ArcGIS document.

\section{Sources of InVEST inputs}

For the present study, the definition of the inputs related to the biological data, valuation data, commercialization of the catches and data on fishing activity were obtained from literature sources, fisheries production data of the Catalan Fisheries Directorate database and spatial distribution of effort from the Spanish Ministry of Agriculture, Marine Affairs and Environment by analysing vessel monitoring data (VMS) with the QGIS software. The VMS data provided the position of all the fishing boats of Blanes and Palamós for the years 20132015 at an average frequency of 60 minutes. Finally, data on the migratory behaviour (ontogenic changes in spatial distribution) of European hake were obtained by associating the existing bibliographic data (Doumenge 1966, Recasens et al. 1998) with the European hake distribution maps by age extrapolated in QGIS 2.10.

\section{Areas of interest}

The VMS data were used to establish the extent of fishing activity in the area of interest and to determine the fishing effort at the level of each fishing zone (de- 


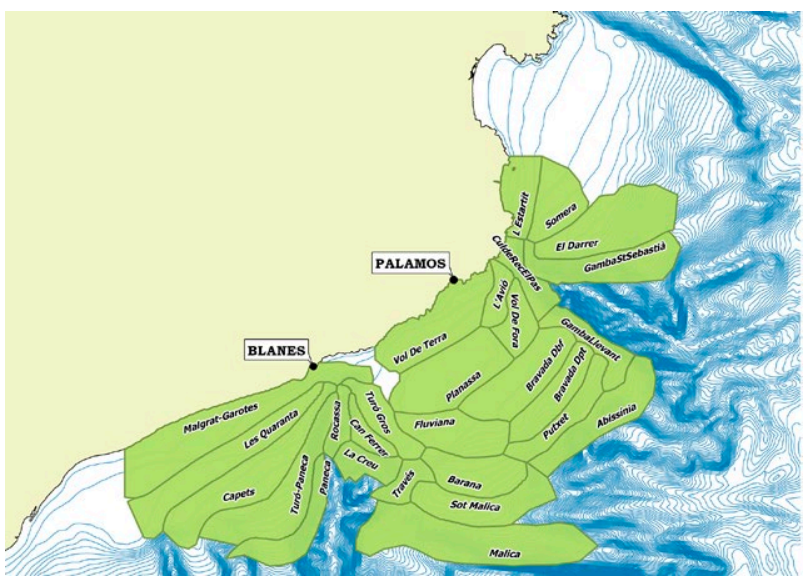

Fig. 2. - Delimitation of InVEST subregions or fishing grounds.

fined in Fig. 2, with local names; see also Supplementary material Table S1). Fishing effort was calculated as number of hours of trawler activity in each cell of a $1 \times 1 \mathrm{~km}$ grid covering the study area (Fig. 3), by filtering fishing vessel signals reporting speeds of between 2 and 4 knots (i.e. fishing tracks). Duplicated positions were deleted. The daily cleaned VMS data were then aggregated by year and averaged. All operations were carried out with QGIS 2.10. The fishing effort map (Fig. 3) indicates a heterogeneous distribution of fishing effort (average for 2013-2015) throughout the study area, which shows that the most exploited fishing grounds are particularly Gamba - St. Sebastià, Sot de la Malica, Barana, Vol de terra, Través, Abissínia, Cul de Rec - El Pas and L'Avió.

\section{The European hake population model}

We modelled the European hake population as 28 subpopulations interconnected via ontogenetic migration, simulating European hake movement from nursery shallow waters to greater depths with age (ages 2, 3 and 4 ). The age-structured population was projected from 2015 to 2025 in annual time steps. Hence, the parameters are based on annual rates and the model progresses in one-year increments.

The European hake population dynamics is given by:

$$
N_{a, x, t}=\left\{\begin{array}{cc}
\operatorname{Rec}_{x, t} & \text { if } a=0 \\
\left(N_{a-1, x, t-1} \operatorname{Mig}_{a-1, x}^{x}+\sum_{x^{\prime} \neq x} N_{a-1, x^{\prime}, t-1} \operatorname{Mig}_{a-1, x^{\prime}}^{x}\right) S_{a-1, x} & \text { if } 1 \leq a<A \\
\left(N_{A-1, x, t-1} \operatorname{Mig}_{A-1, x}^{x}+\sum_{x^{\prime} \neq x} N_{A-1, x^{\prime}, t-1} \operatorname{Mig}_{A-1, x^{\prime}}^{x}\right) S_{A-1, x}+ & \\
+\left(N_{A, x, t-1} \operatorname{Mig}_{A, x}^{x}+\sum_{x^{\prime} \neq x} N_{A, x^{\prime}, t-1} \operatorname{Mig}_{A, x^{\prime}}^{x}\right) S_{A, x} & \text { if } a=A
\end{array}\right\}
$$

where $N_{a, x, t}$ is the number of individuals of age $a(A$ $=$ maximum age) in the area $x$ at the start of time step $t ; S_{a-1, x}$ is survival from natural and fishing mortality from age $a-1$ to $a$ for each area; $R e c_{x, t}$ is recruitment of new individuals/number of offspring; and Mig $_{a, x^{\prime}}$ is the proportion of individuals of age $a$ that migrate from area $x^{\prime}$ to area $x$ (or the proportion that remain in the area if $x^{\prime} 0=x$ ).

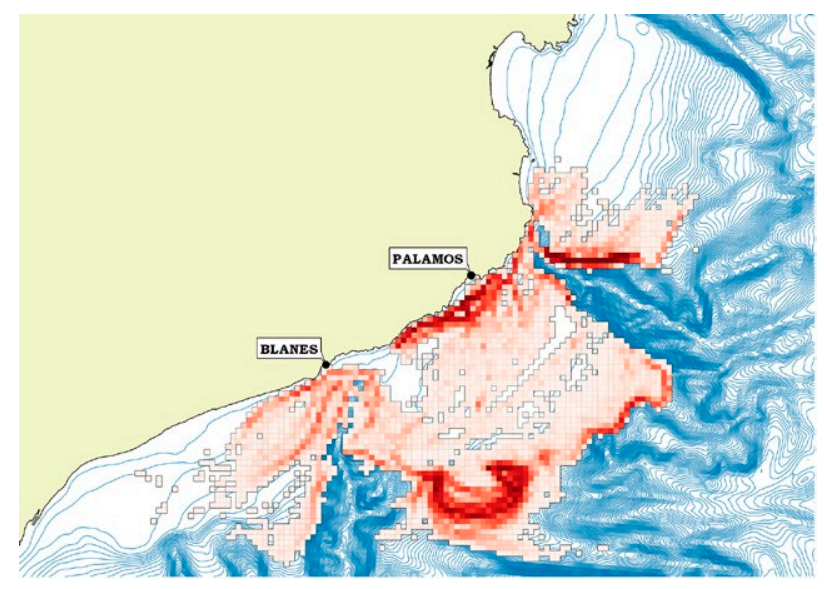

Fig. 3. - Distribution of fishing effort over the study area (units: trawling hours/year, average 2013-2015).

Harvest is assumed to occur at the beginning of the year, before the mortality from natural causes. Harvest $\left(H_{x, t}\right)$ from each subregion in the final (equilibrium) time step is calculated on the basis of user-defined exploitation rate(s) and vulnerability. It is given by:

$$
H_{t, x}=\Sigma_{a,} N_{a,,} \cdot E x_{x} \cdot V_{a} \cdot W_{a}
$$

where $E x_{x}$ is exploitation, which is the proportion of the population vulnerable to harvest that is actually harvested, $V_{a}$ is vulnerability to harvest for age $a$, and $w_{a}$ is weight for age.

The number of spawners is the product of the number of individuals in each age class for the entire study region and the proportion that are mature by age:

$$
S p_{t}=\Sigma_{a,} N_{a,-1} \text { Maturity }_{a}
$$

The biomass of spawners is the product of the number of individuals in each age class for the entire study region, the proportion that are mature at each age and their weight at a given age:

$$
B S p_{t}=\Sigma_{a,} N_{a,-1} \text { Maturity }_{a} W_{a}
$$

where $W_{a}$ is weight by age.

We consider the hypothesis of fast growth for European hake, with a maximum age of approximately 15 years (García-Rodríguez and Esteban 2002, Mellon-Duval et al. 2010), but demographic data for the study area revealed only five age classes. Thus, five age classes of the species were considered, with a group 5+ that represents the maximum age class and includes all individuals of this age and individuals of more than 5 years. We pooled both sexes in the data, as fishing practices or sale of landings are independent of sex. Maturity at age were derived from the Data Collection Framework, in STECF (2015) The biological parameters used as inputs are presented in Supplementari material Tables S2-S5.

Survival from natural mortality is the proportion of individuals that continue to the next age. It is calculated from the instantaneous natural mortality rates $\left(M_{a}\right)$ as

$$
S_{a}=e^{-M_{a, t}}
$$


where $t$ is the duration of the temporary step over which the survival is calculated (one year).

Estimating that the largest age of European hake is 15 years, the vector of natural mortality by age was calculated from the formula of Caddy, using the PROBIOM Excel spreadsheet (Abella et al. 1997), and considering that natural mortality decreases with the older ages (Supplementary material Table S6).

The exploitation fraction $(E x)$ in InVEST refers to the proportion of the vulnerable and effectively captured population in each subregion with the effort applied (0 $=0 \%$ captured, $1=100 \%$ captured). Each subregion is treated independently. In this study, the calculation of this proportion was based on the fishing effort data available in the study area through the VMS data. By means of the spatial union of the two layers, "subregions" (Fig. 2) and "effort" (Fig. 3), with the QGIS software, the average effort in each subregion was calculated. The maximum exploitation fraction $=1(100 \%)$ was attributed to the subregion Gamba - St. Sebastià which recorded the highest fishing effort. We calculated the exploitation fraction of the other subregions based on this fishing ground (Supplementary material Table S7).

Vulnerability to fishing may depend on size, specific behaviour of the species during a life stage, habitat use or regulations, and may change depending on fishing gear and fishing strategies. A value of 1.0 indicates that age is totally vulnerable to fishing, while values below 1 indicate vulnerability relative to fully vulnerable age. It is assumed that the vulnerability is the same in all subregions. On this basis, vulnerability is calculated by observing the values of fishing mortality applied to each age (Supplementary material Table S8). According to the stock assessment of 2015, age 2 represent the age totally vulnerable to fishing (STECF 2015).

\section{Recruitment submodel}

In the case of European hake, as for other Mediterranean fishery stocks, it is difficult to define the relationship between spawning stock biomass (SSB) and recruitment with any degree of certainty. In addition, the stock assessment figures in GSA 6 show considerable fluctuations in European hake recruitment in the last two decades, which may result from a predominance of environmental factors in the recruitment process, rather than a direct relationship between SSB and recruitment. We therefore examined the simulation results under two major hypotheses about the recruitment function assumed in the InVEST model. We first considered the hypothesis of a fixed recruitment function $(\mathrm{H} 1)$, and then analysed the results assuming a linear recruitment (fecundity function: H2). The fecundity function assumes a constant reproductive rate for adults while the fixed recruitment function assumes that recruitment is constant and not dependent on the number of adults. The parameterization of each function is given by

Fixed recruitment function:

$$
\text { Rec }_{x}=\text { LarvalDispersal }_{x} \times \text { Recruitment }
$$

Fecundity function:

Rec $_{x, t}=$ LarvalDispersal $_{x} \times\left(\Sigma_{a, x} N_{a, x, t-1}\right.$ Maturity $_{a}$ Fecundity $\left._{a}\right)$

To determine the initial number of recruits, a virtual cohort analysis was carried out using VIT (Version 1.3). We incorporated the data of length frequency, maturity of the different age classes, the European hake catch for 2015 and the other required population parameters proportionally scaled to the study area (Supplementary material Table S9).

In the case of the linear recruitment function (fecundity), InVEST requires the age-specific fecundity values representing the number of descendants (offspring) per mature individual. These fecundity coefficients refer to the number of European hake eggs and larvae that survive and become recruits. Knowing the number of eggs per female of mature European hake (Recasens et al. 2008), we need to know the daily mortality rates of the eggs of the species to define the number of survivors corresponding to the recruits.

First, based on the observations of European hake individuals in MEDITS (2012-2013) and in the commercial fishing data, we calculated the number of eggs per individual through the equation of Recasens et al. (2008):

$$
y=0.0026 x^{2.8349}
$$

where $y$ is fecundity (number of eggs, in thousands) and $x$ is size in $\mathrm{cm}$.

Length to age conversion (slicing) allowed us to estimate the average number of eggs for each age class, considering the MEDITS observations for ages 0,1 and 2 and the commercial fishing observations for the higher ages (Supplementary material Fig. S1). Given the number of eggs $\left(N_{0}\right)$, we applied an exponential model of decreasing abundance (average density) with respect to age to define the average number of recruits per European hake age class:

$$
N_{a}=N_{0} e^{-Z_{a, t}}
$$

where $N_{a}$ is abundance at age $a, N_{0}$ is estimated abundance at hatching, $Z$ is instantaneous mortality coefficient (daily) and $a$ is age in days.

The data presented in the literature indicate that mortality rates of eggs and larvae of demersal fish with pelagic eggs in general must be high and variable both between years and between populations. The range of mortality rates observed is $7 \%$ to $67 \%$ per day. Daan (1981) found a daily mortality rate of $22 \%$ for cod eggs in the North Sea. To be able to define this daily mortality rate of European hake eggs, we parameterized the model according to the catches observed in 2015 (of the order of $70 \mathrm{t}$ ), and considering an interval of 60 to 120 days of egg development. The best combination provided a daily mortality of $12 \%(0.1193)$ during a period of 90 days. Based on this, the result of the fecundity coefficients by age is presented in Supplementary material Table S5.

The combination of the sampling data of MEDITS cruises with the commercial fishing series of the 
longline fleet (which exploits the older age classes) allowed us to draw a distribution of the different age classes and to exploit the available observations to make an interpolation of the spatial distribution of European hake throughout the study area. The interpolation of the available data provided the spatial distribution of each age class by depth ranges (Supplementary material Fig. S1). The interpolation method used is inverse distance weighting in QGIS.

As an input required by InVEST, the "larval dispersal" represents the proportion of the cumulative larvae pool that disperses into each subregion. For models with subregions (as defined by the fishing grounds, Fig. 2), the model assumes that adults from each subregion contribute to a common larval pool. Larvae are then distributed across subregions. To model the distribution of the larvae among the 28 subregions of interest, considering the lack of large-scale studies on the dispersal and behaviour of European hake larvae, we assumed the same spatial distribution of larvae and age 0 individuals throughout the study area. We used the QGIS software to interpolate the densities of age 0 over the entire study area [MEDITS cruises (20122013) and commercial fishing data]. Given that the dispersal across all subregions should add up to 1 , a total density value is extracted in each subregion and then expressed as a relative density to the total density of age 0 individuals throughout the subregions of interest (Supplementary material Fig. S2).

The migration submodel of InVEST allows European hake movements between the subregions to be integrated and was applied here with high uncertainty because no study on European hake ontogenetic migration had been conducted in our study area. To limit the uncertainty of this submodel, the results were analysed in two parts, first without considering migration and second taking into account the ontogenetic migration of European hake, and the sensitivity of the outputs to this submodel are discussed.

To map the migration of European hake in this model, we consider the migration diagram proposed by Doumenge (1966), the existing literature and the European hake density maps by age resulting from the interpolation of the MEDITS abundance and commercial fishing data in the QGIS software. We conclude that migration occurs for three main ages: age 2, age 3 and age 4 , with an increasing distribution towards deeper fishing grounds with age (Ontogenic migration). Combining all these data, we defined the probable direction of the migration between fishing grounds, and consequently the migration coefficients for the three ages (Supplementary material Table S10).

Valuation, $V_{\mathrm{t}, \mathrm{x}}$ reflects the earnings from the sale of the harvest. It is intended to give a rough idea of the current market value for an equilibrated population based on user-defined price parameters. It is simply

$$
V_{t, x}=H_{t, x} \times \text { FractionProcessed } \times \text { Price }
$$

where Price is the value in price per units (where units match those given by $H_{x}$ ) and FractionProcessed is the proportion of each harvest unit that remains to be sold after processing. To define the unit price of the catch, we referred to the European hake fishing statistics in the ports of Palamós and Blanes (Catalonia Fisheries Statistics, 2000-2015), giving an average price of 8.16 euros $\mathrm{kg}^{-1}$. On the other hand, the "Fraction Kept After Processing" is 1 , as the species is sold as a fresh product without processing.

\section{Sensitivity analysis of the InVEST model}

The various parameters used in this study were implemented with a certain level of uncertainty, so we included the effect of the uncertainty in the results for a better interpretation. The sensitivity of the results to the submodels and the most uncertain parameters in this study are analysed, namely: the European hake growth parameters $( \pm 10 \%)$ and by default natural mortality, daily mortality rate $(Z)$ in the calculation of fecundity coefficients $( \pm 10 \%)$ and, finally, the submodels of recruitment and migration. For this analysis, we proposed new input matrices each time, executed the program again and collected the results of the new simulations. The results of sensitivity analysis are presented in the form of principal component analysis (PCA).

\section{Simulation scenarios}

The InVEST fisheries model facilitates comparison of fisheries production under different scenarios. In our study, we used InVEST to analyse the bioeconomic effect of a spatial management measure (MPA) and various cases of effort limitation in different fishing grounds of the study area, and then to compare the short-, medium- and long-term results of the management scenarios. The selected scenarios are consistent with the requirements of Council Regulation (EC) $1967 / 2006$, regarding the inclusion of spatial aspects such as the establishment of protected fishing zones in order to protect nurseries and/or spawning areas for the sustainable exploitation of fishery resources in the Mediterranean Sea, and with the recommendations of the General Fisheries Commission for the Mediterranean that encourage the reduction of fishing effort in Mediterranean fisheries.

\section{Scenario 1: Spatial closures}

The first scenario consisted of the introduction of spatial closures in areas representing the essential habitats of European hake recruits in order to limit the fishing pressure at their level. Among the fishing areas with a high abundance of recruits, we selected the shallow fishing grounds located closer to the edge of the continental shelf (average depth $\leq 200 \mathrm{~m}$ ) as the most likely to coincide with the habitat of European hake recruits. Then, we studied the effect of closing each of these six fishing zones: Vol de Terra (75 m), L'Avió (99 m), Planassa $(111 \mathrm{~m})$, Vol de fora (130 m), Bravada Dbf (141 $\mathrm{m})$ and Cul de Rec - El Pas (182 m). The main scenario evaluated was the closure of the fishing ground Vol de Terra, which was proposed by the fishing sector during the participatory sessions organized by the MINOUW 
project (http://www.minouw-project.eu) in the period 2015-2016, as a step towards joint co-management of the demersal fishery in the area. The fishing sector and the fisheries administration perceived that closing this fishing ground to fishing would help protect European hake and other fisheries resources (e.g. red mullet) and sensitive habitats (Posidonia beds are located in the shallowest reaches of this fishing ground).

\section{Scenario 2: Reduction of fishing effort}

The second scenario consisted of the application of reductions in the fishing effort for the trawl fleet in our study area, taking into account the distribution map of the effort in the established subregions.

\section{RESULTS}

\section{Sensitivity analysis}

\section{Sensitivity of the results to InVEST submodels}

The PCA carried out to analyse the effect of the two InVEST submodels that we parameterized with most uncertainty, namely, the selected recruitment function (fixed or fecundity) and the migration matrix is shown in Figure 4A. The first two factorial axes of the PCA accounted for $99.51 \%$ of the total variability. It is noted that all the outputs of the model showed a positive correlation with the first component, which differentiates between the simulations with positive impact on the catch: the SSB and the abundance. The second component showed a positive correlation with the capture and the SSB in the short term and a negative correlation with the other outputs, but with a small contribution $(1.18 \%)$. We conclude that the integration of the migration submodel when a constant recruitment is assumed has a limited effect on the results. The results were highly sensitive to the recruitment submodel when a linear SSB-R relation was assumed for European hake. In this case, the migration submodel also had an important effect on the results through a considerable increase in the total catch, abundance and SSB owing to the high sensitivity of the productivity to any change in the fecundity of the species.

\section{Sensitivity to population parameters}

In the PCA (Fig. 4B), the factorial axes F1 and F2 accounted for $99.54 \%$ of the total variation. The first axis had the highest contribution $(+82 \%)$ and sets the parameters that positively affected all the outputs against those that had an opposite effect on all the output variables. The second axis contributed $17 \%$ to the total variation and sets the parameters with a positive correlation with the long-term capture and the abundance at the end of the simulation against the parameters that negatively affected the indicators in the short term.

This analysis shows that the parameters that had the greatest impact on the results were the fertility coefficients. In addition, it is noted that when one is working with a linear recruitment, varying the daily mortality rate $(\mathrm{Z})$ or the growth parameters $(\mathrm{G})$ of the species directly affects the fertility coefficients and generates quite different results. A low daily mortality $(\mathrm{F}+)$ (high fertility) or high growth parameters $(\mathrm{G}+\mathrm{F})$ (low natural mortality) lead to an increase in the assumed fertility and result in an increase in the total catch, the SSB and the abundance, especially in the long term. On the other hand, a slow growth (G-) or a higher daily mortality rate of European hake $(\mathrm{F}-)$ lead to a reduction of the productivity variables.

In the case of constant recruitment, the growth parameters affected the results positively when fast growth was assumed, and negatively when slow growth was assumed. However, this effect was limited compared with the sensitivity shown by the parameters under the issue of linear recruitment.

\section{Impact of the management measures}

The results of the present study were analysed in two parts (with or without the migration aspect) and under two main hypotheses (constant and linear recruitment). This allowed us to consider the effect of the two submodels of InVEST parameterized with more uncertainty in the representability of the results. Firstly, we explored the effect of the closure of fishing grounds (Supplementary material Tables S7, S8) and selected those with the most important effect on the results. Then we compared the effect of the MPAs selected (A1, A2, A3, A6) with the effect of effort limitation $(-10 \%$ and $-20 \%)$.

In the cases analysed, we conclude that it would be beneficial to close the Vol de terra fishing ground (A1) among the other MPA scenarios (Fig. 4C, E). The application of an MPA in Vol de terra seemed to have the best effect on the biological indicators representing abundance and SSB (Fig. 5A). In addition, the analysis of the results with linear recruitment showed the benefit of this MPA in the medium and long term and for all indicators, including total catch, which recovered over time (Fig. 5B). The recruitment function showed higher values for all the indicators because the time evolution of each indicator showed an increasing trend. Thus, all the results were presented relatively to the baseline scenario.

The beneficial effect of the Vol de terra MPA on the indicators was also maintained, when the ontogenetic migration of the European hake for ages 2, 3 and 4 was considered. In this case, we observed another fishing ground ( $\mathrm{Cul}$ de $\mathrm{Rec}-\mathrm{El}$ Pas) whose closure may also be beneficial for the fishery, with similar results to those of the Vol de terra MPA (Figs 6 and 7). In addition, considering European hake migration involved a change in the distribution of the catch and abundance in the different subregions, with an increase in catch and/ or abundance in some fishing grounds, and a decrease in others in response to the direction of displacement with migration (according to depth) (Table 1).

The closure of Vol de terra is approximately equal to a reduction in fishing effort of up to $20 \%$ in the entire area of interest (Fig. 4D, F), which would be equivalent to the interruption of fishing activity for one day per 
Biplot (axes F1 et F2 : 99.51 \%)
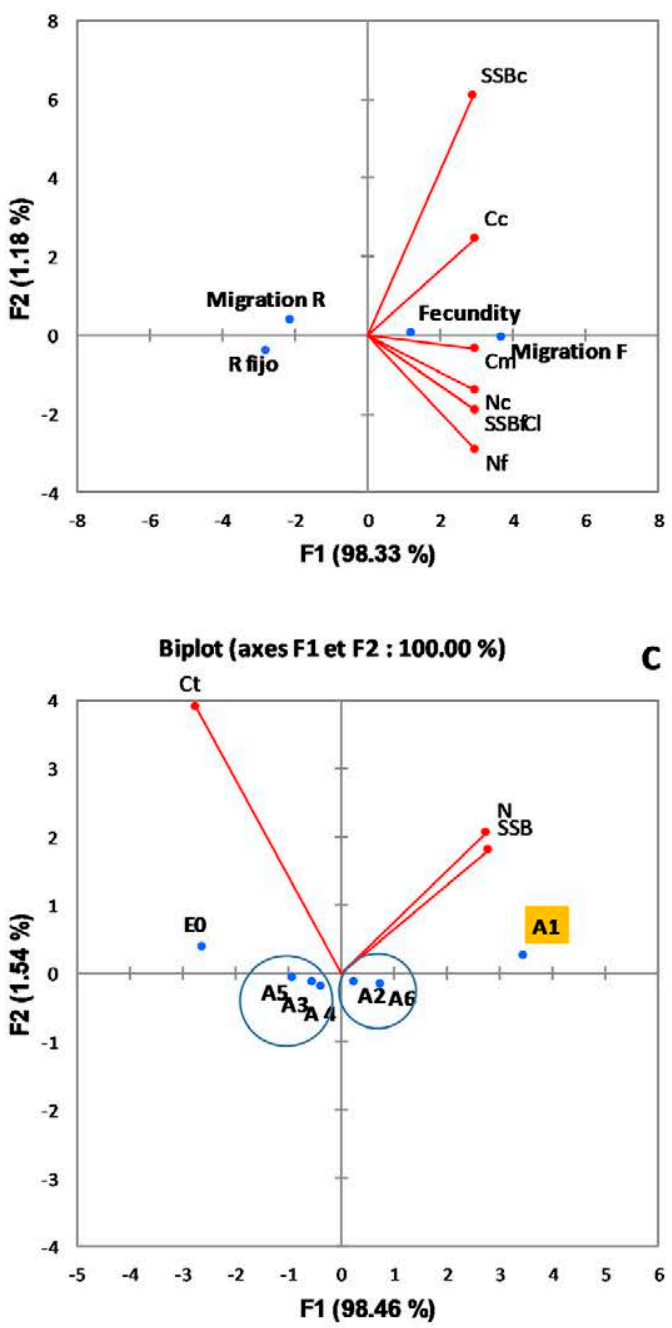

Biplot (axes F1 et F2 : $100.00 \%$ )

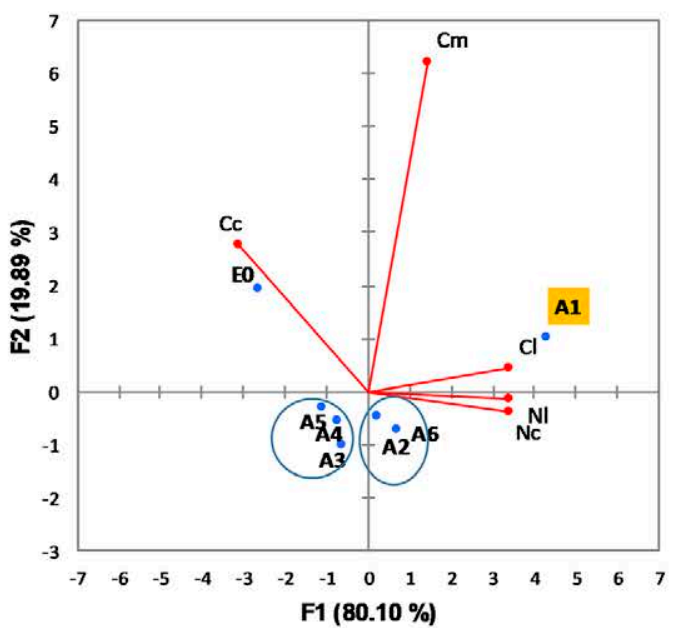

C

$\mathbf{E}$
Biplot (axes F1 et F2 : $99.54 \%$ )

B

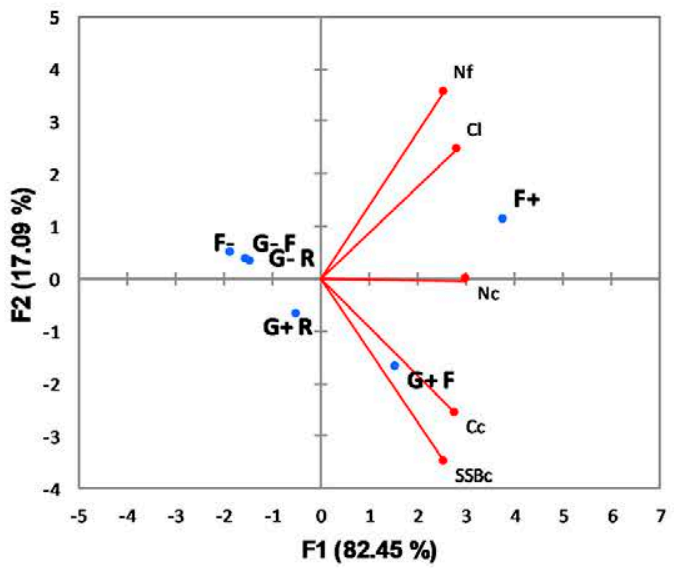

Biplot (axes F1 et F2 : $\mathbf{1 0 0 . 0 0 \% ) ~}$

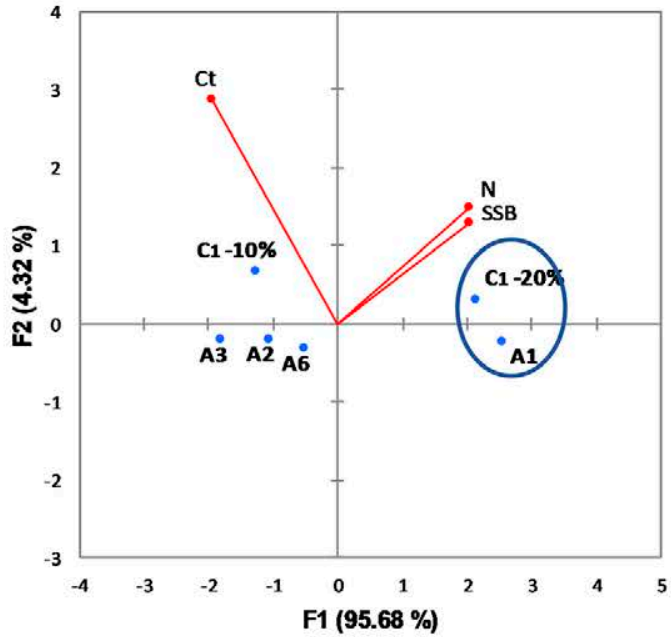

Biplot (axes F1 et F2 : 99.99 \%)

$\mathbf{F}$

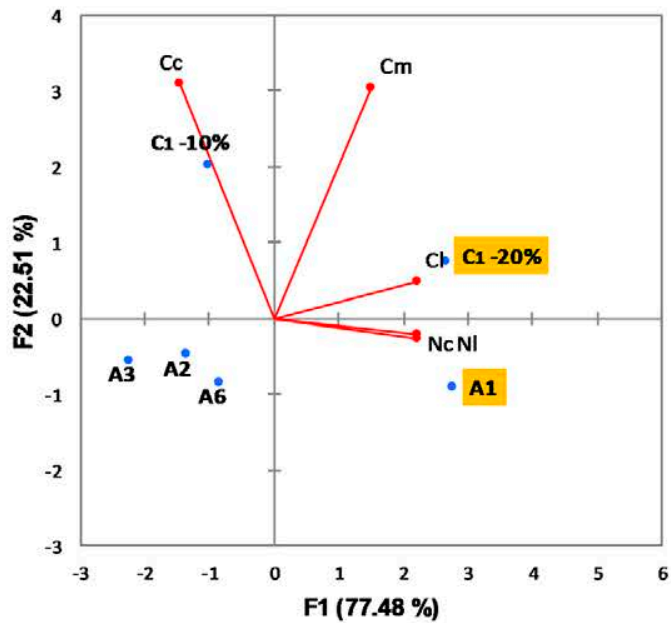

Fig. 4. - PCA results. A, sensitivity analysis of the indicators to the submodels Recruitment and Migration; B, sensitivity analysis of the indicators to the parameters $(\mathrm{G}+$, fast growth, $\mathrm{G}-$, slow growth, $\mathrm{F}+$, low daily mortality, $\mathrm{F}-$, high daily mortality); $\mathrm{C}$, comparison between spatial management scenarios, constant recruitment; D, comparison between spatial and non-spatial management scenarios, constant recruitment; E, result of spatial management, linear recruitment; F, comparison between spatial and non-spatial management scenarios, linear recruitment. Legend: R, fixed recruitment; F, linear recruitment. Cc, short-term catch; Cm, medium-term catch; Cl, long-term catch; Nc and Nf, short-term and end-of-simulation abundance; N1, long-term abundance; E0, baseline scenario; A1, MPA in Vol de Terra; A2, MPA in L'Avió; A3, MPA in Planassa; A4, MPA in Vol de fora; A5, MPA in Bravada Dbf; A6, MPA in Cul de Rec-El Pas; C1-10\% and C1-20\%, reduction of effort by $10 \%$ and $20 \%$ in the entire study area. 
A

Total catch (Ct)

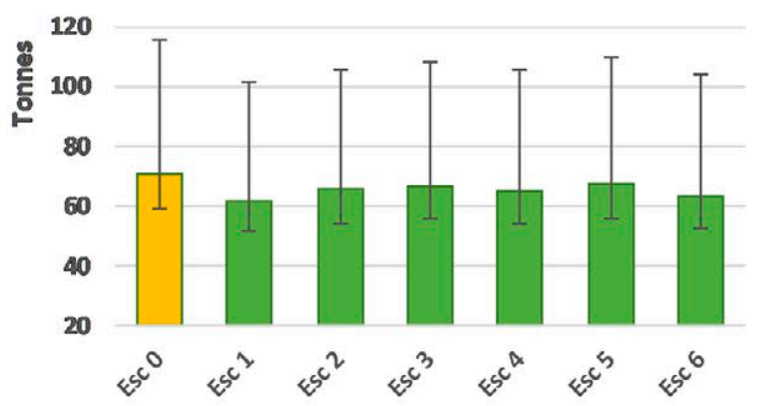

Abundance (N)

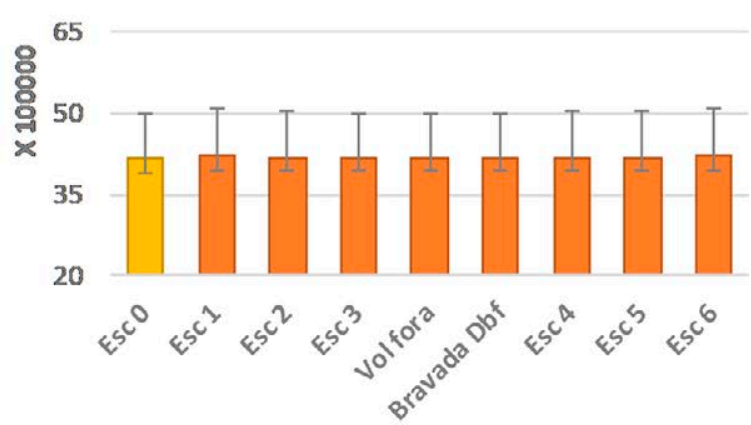

B

Total catch (Ct)

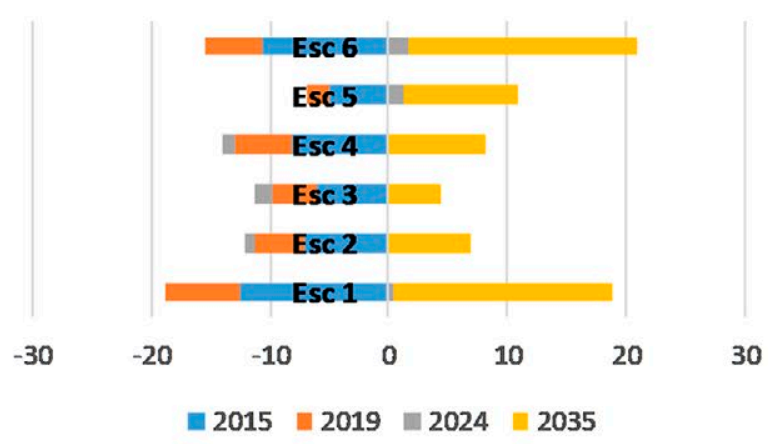

Abundance

50

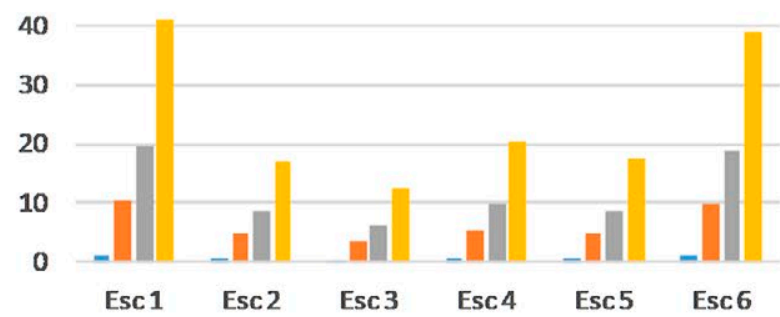

$2015 \square 2019 \quad 2024=2035$
Income (I)

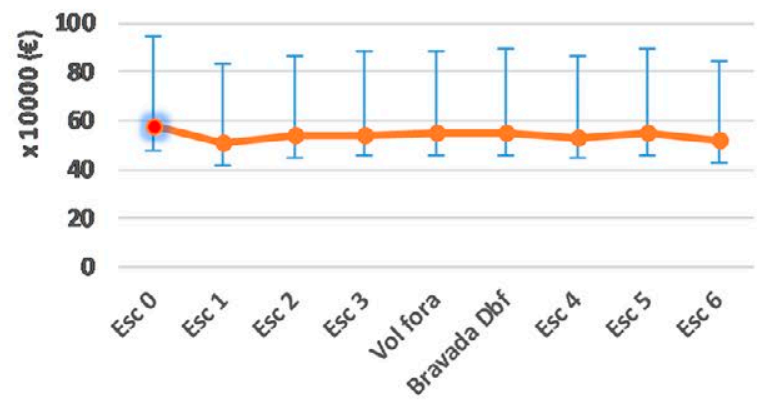

SSB

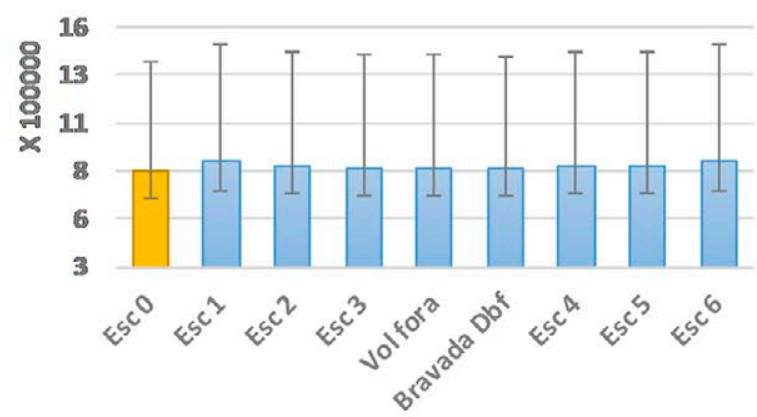

Recruitment

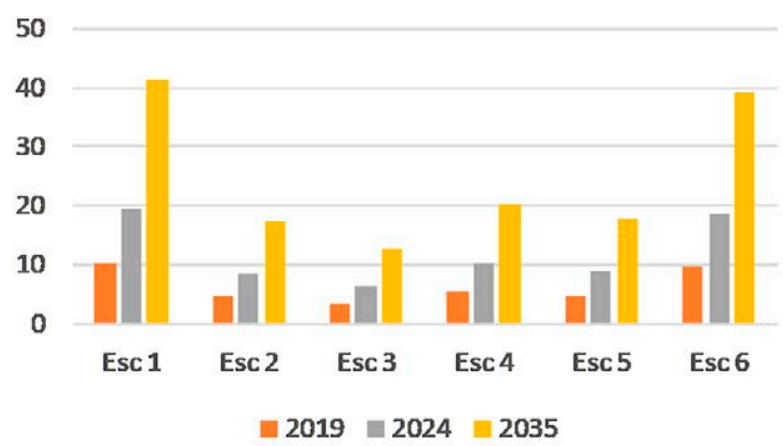

SSB

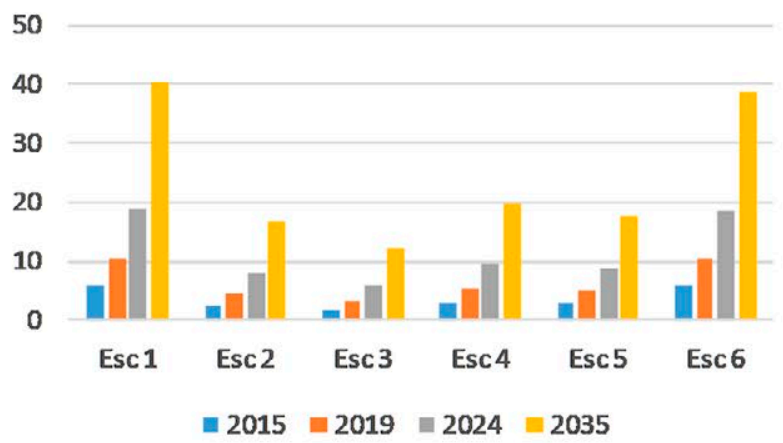

Fig. 5. - Result of the management scenarios in relative terms to the baseline scenario, A, fixed recruitment; B, linear recruitment. Esc 1 - A1, MPA in Vol de Terra; Esc 2-A2, MPA in L'Avió; Esc 3 - A3, MPA in Planassa; Esc 4 - A6, MPA in Cul de Rec - El Pas; Esc 5 - reduction of effort by $10 \%$ (in the entire study area); Esc 6, reduction of effort by $20 \%$ (in the entire study area). 


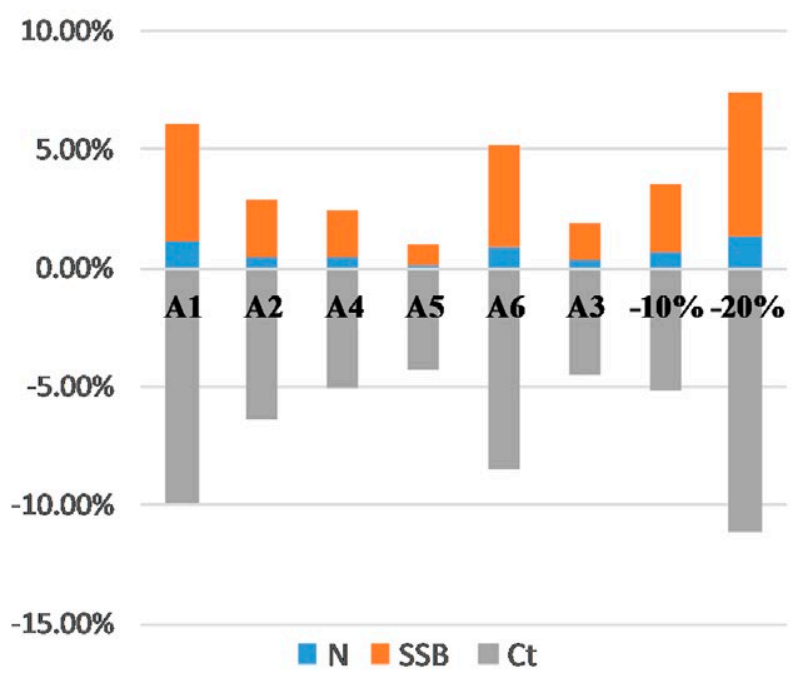

Fig. 6. - Result of the indicators under the management scenarios and in relative terms to Esc 0, (migration submodel, constant recruitment). N, abundance; SSB, spawning stock biomass, $\mathrm{Ct}$, total catch; A1, closure of Vol de Terra; A2, A4, A5, A6, A3: closure of L'Avió, Vol de fora, Bravada Dbf, Cul de Rec - El Pas and Planassa; $-10 \%$, reduction of effort by $10 \% ;-20 \%$, reduction of effort by $20 \%$.

\section{Ct}

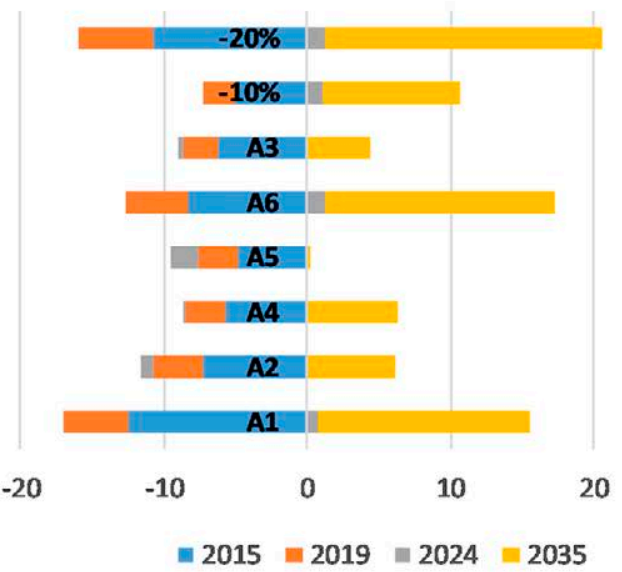

Abundance

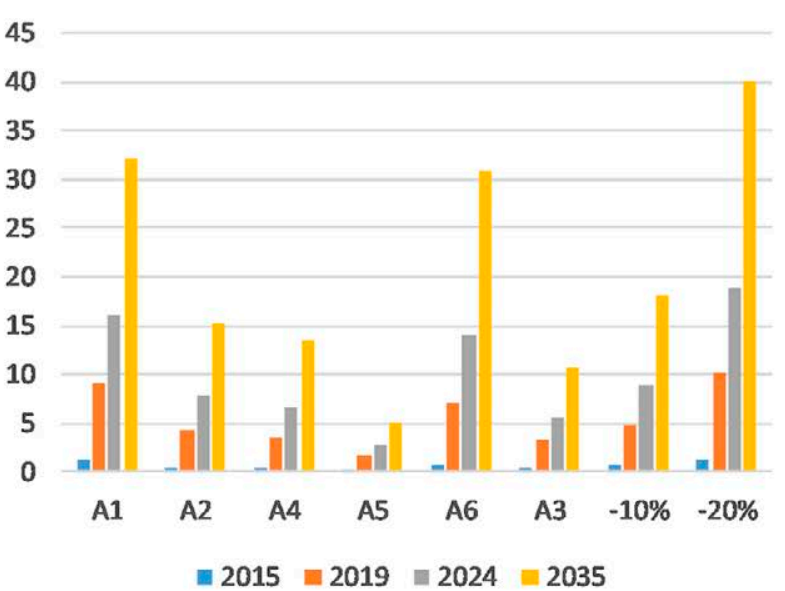

week. When considering the migration of European hake, the results also revealed that the effect of this MPA is quite close to the effect of reducing fishing effort by 20\% (Figs 6 and 7). Finally, InVEST produced distribution maps of catch and income in each fishing ground and for each management scenario. We present specifically the distribution of catch in a response to the closure of Vol de Terra as the incomes show the same distribution as catches (Fig. 8).

\section{DISCUSSION}

This work represents the first application of the InVEST model to a specific case of demersal fishery in the Spanish Mediterranean. It is also the first attempt to pre-evaluate the effect of spatial management on an overexploited fishery of great interest for the fishing sector in Catalonia.

Throughout this study, we have evaluated the effect of the application of an MPA at the level of the Vol de Terra fishing ground, which seems to be an essential habitat for European hake recruits, together with

\section{Recruitment}

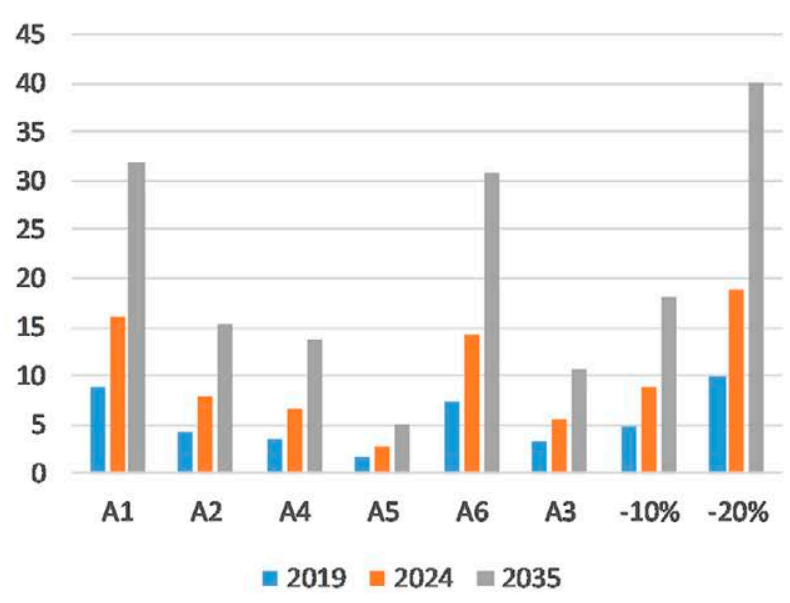

\section{SSB}

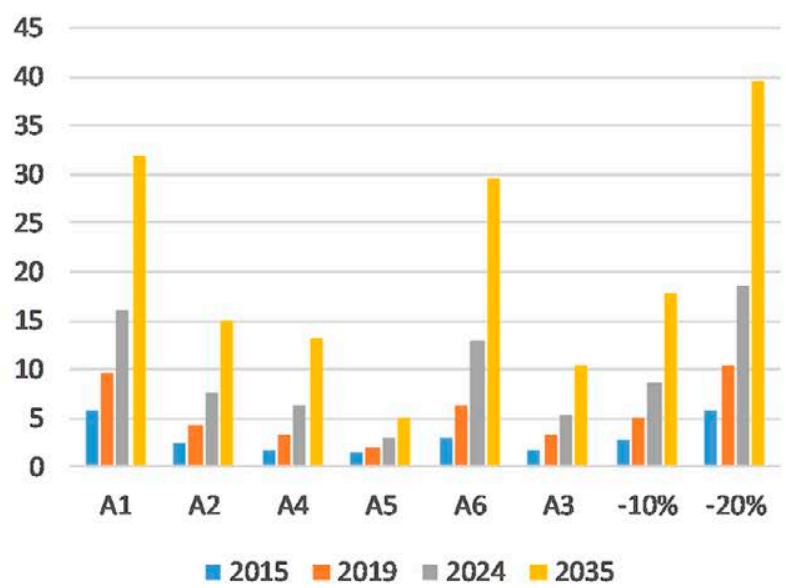

Fig. 7. - Result of the biological indicators of European hake relative to the baseline scenario (migration submodel, linear recruitment). A1, closure of Vol de Terra; A2, A4, A5, A6, A3, closure of L'Avió, Vol de fora, Bravada Dbf, Cul de Rec-El Pas and Planassa; -10\%, reduction of effort by $10 \% ;-20 \%$, reduction of effort by $20 \%$. 
Table 1. - Effect of MPA Vol de Terra on results, highlighting in bold face the main fishing grounds (Area) contributing with recruits to MPA Vol de Terra.

\begin{tabular}{|c|c|c|c|c|c|c|c|c|c|c|}
\hline \multirow{4}{*}{ Area } & \multicolumn{8}{|c|}{ Migration } & \multirow{3}{*}{\multicolumn{2}{|c|}{$\begin{array}{c}\text { Not considering migration } \\
\text { Effect of Vol de Terra MPA (A1) } \\
\text { SSB-R lineal }\end{array}$}} \\
\hline & \multicolumn{4}{|c|}{ Constant recruitment } & \multicolumn{4}{|c|}{ Linear recruitment } & & \\
\hline & \multicolumn{2}{|c|}{ Scenario 0} & \multicolumn{2}{|c|}{ MPA 1} & \multicolumn{2}{|c|}{ Scenario 0} & \multicolumn{2}{|c|}{ MPA 1} & & \\
\hline & $\mathrm{Ct}$ & $\mathrm{N}$ & $\mathrm{Ct}$ & $\mathrm{N}$ & $\mathrm{Ct}$ & $\mathrm{N}$ & $\mathrm{Ct}$ & $\mathrm{N}$ & $\mathrm{Ct}$ & $\mathrm{N}$ \\
\hline 1 & $7 \%$ & $2 \%$ & $7 \%$ & $2 \%$ & $33 \%$ & $30 \%$ & $25 \%$ & $22 \%$ & $35 \%$ & $39 \%$ \\
\hline 2 & $-21 \%$ & $-5 \%$ & $-21 \%$ & $-5 \%$ & $2 \%$ & $23 \%$ & $-3 \%$ & $15 \%$ & $35 \%$ & $40 \%$ \\
\hline 3 & $\mathbf{5 0 \%}$ & $14 \%$ & $51 \%$ & $14 \%$ & $82 \%$ & $44 \%$ & $71 \%$ & $34 \%$ & $35 \%$ & $39 \%$ \\
\hline 4 & $12 \%$ & $3 \%$ & $12 \%$ & $3 \%$ & $38 \%$ & $31 \%$ & $30 \%$ & $23 \%$ & $35 \%$ & $39 \%$ \\
\hline 5 & $7 \%$ & $1 \%$ & $7 \%$ & $1 \%$ & $34 \%$ & $30 \%$ & $26 \%$ & $21 \%$ & $37 \%$ & $40 \%$ \\
\hline 6 & $5 \%$ & $1 \%$ & $5 \%$ & $1 \%$ & $32 \%$ & $30 \%$ & $24 \%$ & $21 \%$ & $37 \%$ & $40 \%$ \\
\hline 7 & $-18 \%$ & $-4 \%$ & $-18 \%$ & $-4 \%$ & $4 \%$ & $23 \%$ & $-1 \%$ & $16 \%$ & $35 \%$ & $39 \%$ \\
\hline 8 & $1 \%$ & $0 \%$ & $3 \%$ & $1 \%$ & $26 \%$ & $28 \%$ & $22 \%$ & $21 \%$ & $35 \%$ & $39 \%$ \\
\hline 9 & $2 \%$ & $1 \%$ & $2 \%$ & $1 \%$ & $27 \%$ & $29 \%$ & $20 \%$ & $21 \%$ & $35 \%$ & $39 \%$ \\
\hline 10 & $-16 \%$ & $-4 \%$ & $-16 \%$ & $-4 \%$ & $8 \%$ & $25 \%$ & $2 \%$ & $17 \%$ & $35 \%$ & $40 \%$ \\
\hline 11 & $5 \%$ & $1 \%$ & $6 \%$ & $1 \%$ & $31 \%$ & $30 \%$ & $24 \%$ & $22 \%$ & $35 \%$ & $39 \%$ \\
\hline 12 & $2 \%$ & $1 \%$ & $2 \%$ & $1 \%$ & $28 \%$ & $29 \%$ & $21 \%$ & $21 \%$ & $35 \%$ & $39 \%$ \\
\hline 13 & $12 \%$ & $2 \%$ & $15 \%$ & $3 \%$ & $39 \%$ & $31 \%$ & $34 \%$ & $23 \%$ & $36 \%$ & $40 \%$ \\
\hline 14 & $593 \%$ & $178 \%$ & $630 \%$ & $190 \%$ & $696 \%$ & $223 \%$ & $671 \%$ & $205 \%$ & $35 \%$ & $39 \%$ \\
\hline 15 & $3 \%$ & $1 \%$ & $3 \%$ & $1 \%$ & $28 \%$ & $29 \%$ & $21 \%$ & $21 \%$ & $35 \%$ & $39 \%$ \\
\hline 16 & $24 \%$ & $2 \%$ & $24 \%$ & $2 \%$ & $53 \%$ & $31 \%$ & $43 \%$ & $22 \%$ & $38 \%$ & $41 \%$ \\
\hline 17 & $6 \%$ & $2 \%$ & $7 \%$ & $2 \%$ & $32 \%$ & $30 \%$ & $25 \%$ & $22 \%$ & $35 \%$ & $39 \%$ \\
\hline 18 & $-5 \%$ & $-1 \%$ & $-5 \%$ & $-1 \%$ & $19 \%$ & $27 \%$ & $13 \%$ & $19 \%$ & $35 \%$ & $39 \%$ \\
\hline 19 & $1 \%$ & $0 \%$ & $1 \%$ & $0 \%$ & $26 \%$ & $29 \%$ & $19 \%$ & $21 \%$ & $36 \%$ & $40 \%$ \\
\hline 20 & $1 \%$ & $0 \%$ & $1 \%$ & $0 \%$ & $26 \%$ & $28 \%$ & $19 \%$ & $21 \%$ & $35 \%$ & $39 \%$ \\
\hline 21 & $0 \%$ & $0 \%$ & $1 \%$ & $0 \%$ & $25 \%$ & $28 \%$ & $20 \%$ & $21 \%$ & $35 \%$ & $39 \%$ \\
\hline 22 & $-4 \%$ & $-1 \%$ & $-1 \%$ & $0 \%$ & $21 \%$ & $28 \%$ & $17 \%$ & $20 \%$ & $36 \%$ & $40 \%$ \\
\hline 23 & $-8 \%$ & $-2 \%$ & $18 \%$ & $4 \%$ & $17 \%$ & $26 \%$ & $39 \%$ & $24 \%$ & $35 \%$ & $39 \%$ \\
\hline 24 & $-9 \%$ & $-1 \%$ & $0 \%$ & $-7 \%$ & $16 \%$ & $28 \%$ & $0 \%$ & $14 \%$ & $-100 \%$ & $66 \%$ \\
\hline 25 & $129 \%$ & $34 \%$ & $170 \%$ & $44 \%$ & $170 \%$ & $65 \%$ & $192 \%$ & $62 \%$ & $35 \%$ & $39 \%$ \\
\hline 26 & $404 \%$ & $84 \%$ & $502 \%$ & $105 \%$ & $498 \%$ & $122 \%$ & $560 \%$ & $125 \%$ & $35 \%$ & $40 \%$ \\
\hline 27 & $112 \%$ & $15 \%$ & $120 \%$ & $16 \%$ & $149 \%$ & $45 \%$ & $138 \%$ & $36 \%$ & $37 \%$ & $40 \%$ \\
\hline 28 & $28 \%$ & $6 \%$ & $31 \%$ & $6 \%$ & $56 \%$ & $35 \%$ & $49 \%$ & $26 \%$ & $35 \%$ & $40 \%$ \\
\hline
\end{tabular}

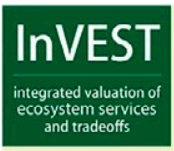

A

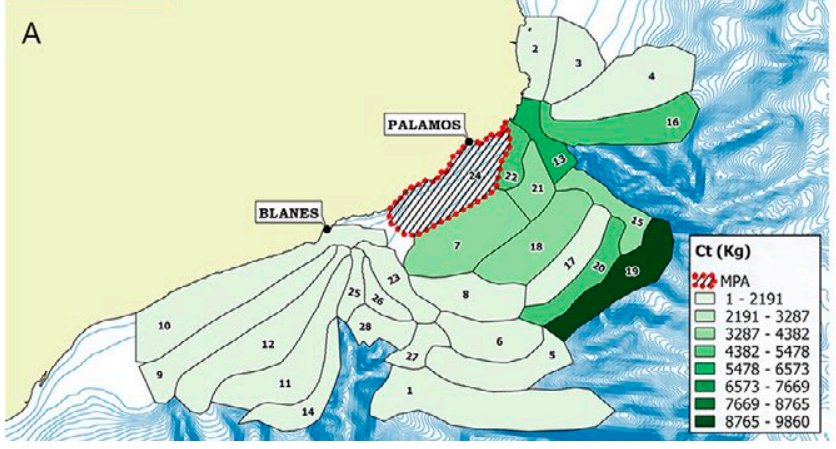

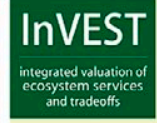

B

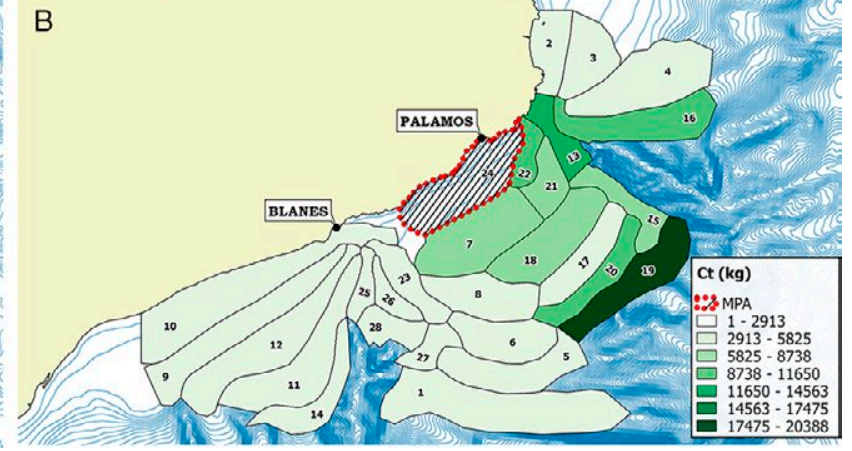

Fig. 8. - Spatial distribution of catch under A1 (MPA in Vol de Terra) at the end of simulation (time t) according to two recruitment models. $\mathrm{A}$, constant recruitment; $\mathrm{B}$, linear recruitment.

other management scenarios in order to compare their efficiency and determine their effect on different biological indicators (abundance, SSB, recruitment) and economic indicators (catch or amount) of the fishery.

\section{The InVEST model and the quality of inputs}

The InVEST model has been treated with a level of uncertainty regarding the quality and availability of the information introduced (inputs). InVEST requires specific data on the biology and population dynamics of the species of interest and data on the fishing activity in the study area. This model allows us to integrate available information about the fishery and use it to explore various management scenarios (Sharp et al. 2016). A particularity of this model is that it needs a limited data volume in comparison with other spatially explicit models: ISIS-Fish (Ifremer 2007) and DISPLACE (Bastardie et al. 2014).

Some submodels and parameters were implemented with more uncertainty than others. Firstly, the relation between SSB and recruitment for European hake remains undetermined throughout GSA6 given the limitation of the historical series of these data. We therefore studied two hypotheses for the recruitment function (constant and linear), analysing the impact of each function on the results, which showed qualitatively similar results. Second, the fecundity coefficients 
proposed in the case of linear recruitment are a source of considerable uncertainty and have a high influence on the results, as there are no scientific studies available on the survival and/or daily mortality of European hake eggs and larvae

Furthermore, in relation to the migration submodel, the migration coefficients were considered with uncertainty due to the absence of mark-recapture studies or other specific studies that explore the migratory behaviour of European hake in the Catalan Mediterranean Sea. The integration of a migration matrix in this study has a more perceptible effect on the results, especially when we consider the hypothesis of linear recruitment, owing to the added uncertainty of the migration coefficients to that of the fertility coefficients.

Subsequently, the parameters of growth and, consequently, natural mortality (resulting from the change of these parameters) affect the results to a lesser extent than the previous parameters and do not change the general conclusions of the study. The uncertainty of the results for these parameters was considered in the representation of the results with confidence intervals, but not in the case of the linear recruitment function, given the high sensitivity shown. We note that European hake tagging studies (from de Pontual et al. 2003, 2012, Mellon-Duval et al. 2010) will be useful to improve knowledge about migration, natural mortality and growth of this species.

All the other parameters considered in this study were obtained from the most recent bibliographic sources and/or from the scientific data available to date (MEDITS), so their effect on the results is estimated as very limited. However, additional research to clarify the dynamics of European hake recruitment through the stations at the level of the study area will improve the information on the density distribution of the recruits and thus delimit the zones of nurseries of the species for better management.

\section{InVEST results}

On top of the problem of over-exploitation, the risks of collapse or depletion of the Mediterranean stocks seem limited (Caddy 1999) due to the high resilience of these stocks compared with Atlantic ones (Lleonart 2005). This is explained by the high exploitation rates of juveniles against the low mortality of adults with the occurrence of refuge zones for adults on the high seas. This high mortality of juveniles significantly affects the productivity and structure of the population (Hidalgo et al. 2009). The average capture size of these stocks is smaller than the size that would produce the maximum yield and suffers high variability due to instability of population dynamics and a decrease in the stocks' capacity to cope with environmental fluctuations (Anderson 2008).

Given the multi-specific peculiarity of Mediterranean fisheries, a combination of management tools based only on technical measures and effort control has not managed to guarantee the long-term sustainability of fisheries or the conservation of important habitats (Colloca et al. 2013, Tudela 2004). Therefore, the implementation of management measures to protect aggregation areas of juveniles during their first year of life has the potential to substantially improve the present fishing exploitation patterns and is a major prerequisite for the sustainability of trawl fisheries in the future (Colloca et al. 2015).

In addition to the results of our study, many studies have shown that the spatial closure of Mediterranean nurseries can provide important benefits to fisheries in terms of increased fishing resistance and improved yields (Apostolaki et al. 2002, Scarcella et al. 2014). It would also allow a better fulfilment of the landing obligation established by the new European Fisheries Policy and a reduction in the high fishing mortality of juveniles of demersal stocks in the Mediterranean (Colloca et al. 2013, Tsagarakis et al. 2014). Spatial restriction of fishing need not be permanent in order to be effective. Cinner et al. (2006) show that periodic closures can have a positive effect on fisheries resources in terms of both catches and biomass conservation. Other management schemes are also possible, such as the periodic rotation of area closures, whose positive effects are demonstrated in Hart and Rago (2006) or "pulse fishing", i.e. restricting fishing on given fishing grounds on alternate years (Da Rocha et al. 2012).

Outside the Spanish Mediterranean, the European hake fishery in the Gulf of Lion (GSA7) (Ifremer 2011) also shows over-exploitation by a mixed fleet, composed mainly of French (88\%) and Spanish (12\%) trawlers fishing small European hake individuals. The pre-evaluation of this fishery through a bioeconomic model (Macher et al. 2010) showed that interrupting the fishing activity of the trawls for one month seems to lead to an improvement in the catch and the SSB, and a decrease in the global and individual performance of the trawling fleet, without reaching the MSY. In addition, this study showed that a reduction of fishing effort by about $15 \%$ per year for four years allows the MSY to be reached with more beneficial results on catch and SSB. In this case, reducing the number of trawls (instead of fishing days) was the only scenario with a positive impact on the individual performance of all boats (trawls, longlines and others).

The analysis of another mixed European hake fishery in the Bay of Biscay using an ISIS-Fish simulation tool (Ifremer 2007) evaluated the effect of spatio-temporal management on the dynamics of this mixed fishery (Drouineau et al. 2006). The parameterization of the ISIS-Fish model requires the same inputs as InVEST, in addition to other additional parameters. The authors concluded that the application of MPAs in the European hake nursery areas improves not only the stock of European hake but also the total biomass, the catches, the SSB and the recruitment of the second species of interest for this fishery. Therefore, this study highlights the interest of MPAs implemented in areas of European hake nurseries and supports the conclusions of our work. In addition, it is suggested through this study that the application of an MPA in our area of interest may be useful for the other demersal species of this mixed fishery, a finding which could not be revealed with InVEST because of its monospecific peculiarity. 
The understanding of spatial patterns in population dynamics is essential to protect critical habitats and ensure sustainable management of fisheries resources (Berkeley et al. 2004, Caddy 2000). In the specific case of European hake, such information on the essential habitats for the reproduction of the species in the Mediterranean will contribute to the good application of the spatial management of fisheries required by the EU and, in particular, to limiting fishing mortality of the recruits (Druon et al. 2015).

To identify the appropriate areas for closure against fishing, many authors have studied the spatial distribution of juvenile European hake at a regional scale and identified the main nursery areas where the highest concentrations of juveniles remain stable over the years (Colloca et al. 2015, Fiorentino et al. 2003, Tserpes et al. 2008). Other studies are based on the use of the ecological niche model for the modelling of potential European hake nurseries in the Mediterranean Sea (Druon et al. 2015).

\section{CONCLUSION}

The present study has shown that a spatially explicit tool such as InVEST can be very useful for preevaluating spatial management measures and choosing among the best possible alternatives for a fishery by integrating a limited number of non-complex data. The present work has allowed us to explore this model to guide decision making in the management of the European hake fishery, which is overexploited in the Mediterranean, and specifically at the ports of Blanes and Palamós. The results of the study coincide with other studies highlighting the benefits of spatial management and confirm the importance of protecting this fishery to sustain the stock of European hake, which is very sensitive to changes affecting juveniles.

The results of this work allow us to draw two main conclusions: First, the closure of the Vol de Terra fishing ground is the best spatial management alternative for the recovery of catches and biomass of European hake in the medium and long term, and would have a minor effect on fisheries performance in the medium term. Fishers are well aware of the importance of this area as a hake nursery, and our work helped confirm their preferences, as expressed during the participatory approach between scientists and stakeholders. According to our results, spatial closures in other fishing grounds would not attain a similar degree of stock protection. Second, the application of an MPA in this fishery would be equivalent to a reduction in fishing effort of $20 \%$ in the entire study area, but it would be easier to implement and would meet with less resistance from the sector than a fishing effort reduction measure.

\section{ACKNOWLEDGEMENTS}

This study received funding from the European Commission's Horizon 2020 Research and Innovation Programme under Grant Agreement No. 634495 for the project Science, Technology, and Society Initiative to Minimize Unwanted Catches in European Fisheries (MINOUW).

\section{REFERENCES}

Abella J., Caddy F., Serena F. 1997. Do natural mortality and availability decline with age? An alternative yield paradigm for juvenile fisheries, illustrated by the hake Merluccius merluccius fishery in the Mediterranean. Aquat. Liv. Res. 10: 257-269. https://doi.org/10.1051/alr:1997029

Anderson C. 2008. Why fishing magnifies fluctuations in fish abundance. Nature 452: 835-839. https://doi.org/10.1038/nature06851

Apostolaki P., Milner-Gulland E.J., McAllister M.K., et al. 2002. Modelling the effects of establishing a marine reserve for mobile species. Can. J. Fish. Aquat. Sci. 59: 405-415. https://doi.org/10.1139/f02-018

Arkema K.K., Verutes G.M., Wood S.A., et al. 2015. Embedding ecosystem services in coastal planning leads to better outcomes for people and nature. Proc. Nat. Acad. Sci. USA 112: 7390-7395.

Bastardie F., Nielsen J.R., Miethe T. 2014. DISPLACE: a dynamic, individual-based model for spatial fishing planning and effort displacement - integrating underlying fish population models. Can. J. Fish. Aquat. Sci. 71: 366-386. https://doi.org/10.1139/cjfas-2013-0126

Berkeley S.A., Chapman C., Sogard S.M. 2004. Maternal age as a determinant of larval growth and survival in a marine fish, Sebastes melanops. Ecology 85: 1258-1264. https://doi.org/10.1890/03-0706

Caddy J.F. 1999. Fisheries management in the twenty-first century: will new paradigms apply? Rev. Fish Biol. Fish. 9: 1-43. https://doi.org/10.1023/A:1008829909601

Caddy J. F. 2000 Marine catchment basin effects versus impacts of fisheries on semi-enclosed seas. ICES J. Mar. Sci. 57: 628-640. https://doi.org/10.1006/jmsc.2000.0739

Christensen V., Pauly D. 1992. ECOPATH II: a software for balancing steady-state ecosystem models and calculating network characteristics. Ecol. Model. 61: 169-185. https://doi.org/10.1016/0304-3800(92)90016-8

Cinner J., Marnane M.J., McClanahan T.R., et al. 2006. Periodic closures as adaptive coral reef management in the Indo-Pacific. Ecol. Soc. 11: 31 https://doi.org/10.5751/ES-01618-110131

Colloca F., Cardinale M., Maynou F., et al. 2013. Rebuilding Mediterranean fisheries: a new paradigm for ecological sustainability. Fish Fish. 14: 89-109. https://doi.org/10.1111/j.1467-2979.2011.00453.x

Colloca F., Garofalo G., Bitetto I., et al. 2015. The Seascape of Demersal Fish Nursery Areas in the North Mediterranean Sea, a First Step Towards the Implementation of Spatial Planning for Trawl Fisheries. PLoS ONE 10: e0119590. https://doi.org/10.1371/journal.pone.0119590

Daan N. 1981. Comparison of estimates of egg production on the Southern Bight cod stock from plankton surveys and market statistics. Rapp. P.-v. Réun. Cons. int. Explor. Mer 172: 39-57.

Da Rocha J.M., Gutiérrez M.J., Antelo L.T. 2012. Pulse vs. Optimal Stationary Fishing: The Northern Stock of hake. Fish. Res. 121122: 51-62. https://doi.org/10.1016/j.fishres.2012.01.009

De Pontual H., Bertignac M., Battglia A., et al. 2003. A pilot tagging experiment on European hake (Merluccius merluccius): methodology and preliminary results. ICES J. Mar. Sci. 60: 1318-1327. https://doi.org/10.1016/S1054-3139(03)00149-8

De Pontual H., Jolivet A., Bertignac M., et al. 2012. Diel vertical migration of European hake Merluccius merluccius and associated temperature histories: insights from a pilot data-storage tagging (DST) experiment. J. Fish Biol. 81: 728-734. https://doi.org/10.1111/j.1095-8649.2012.03345.x

Doumenge F. 1966 Hydrologie, biologie et pêche en Méditerranée occidentale. Bull. Soc. Languedocienne Géogr. (Third Series), 2: $1-34$.

Drouineau H., Mahévas S., Pelletier D., et al. 2006. Assessing the impact of different management options using ISIS-Fish: the French Merluccius merluccius - Nephrops norvegicus mixed fishery of the Bay of Biscay. Aquat. Liv. Res. 19: 15-29. https://doi.org/10.1051/alr:2006002

Druon J.-N., Fiorentino F., Murenu M., et al. 2015. Modelling of European hake nurseries in the Mediterranean Sea: An ecological niche approach. Progr. Oceanog. 130: 188-204. https://doi.org/10.1016/j.pocean.2014.11.005

Fiorentino F., Garofalo G., De Santi A., et al. 2003. Spatio-temporal 
distribution of recruits ( 0 group) of Merluccius merluccius and Phycis blennoides (Pisces, Gadiformes) in the Strait of Sicily (Central Mediterranean). Hydrobiologia 503: 223-236. https://doi.org/10.1023/B:HYDR.0000008485.85468.ef

Garcia-Rodriguez M., Esteban A. 2002. How fast does hake grow? A study on the Mediterranean hake (Merluccius merluccius L.) comparing whole otoliths readings and length frequency distributions data. Sci. Mar. 66: 145-156. https://doi.org/10.3989/scimar.2002.66n2145

Goñi R., Adlerstein S., Alvarez F., et al. 2004. Recruitment indices of European hake, Merluccius merluccius (Linnaeus 1758), in the Northwest Mediterranean based on landings from bottomtrawl multispecies fisheries. ICES J. Mar. Sci. 61: 760-773. https://doi.org/10.1016/j.icesjms.2004.04.002

Hart D.R., Rago P.J. 2006. Long-term dynamics of U.S. Atlantic sea scallop Placopecten magellanicus populations. N. Am. J. Fish. Manage. 26: 490-501. https://doi.org/10.1577/M04-116.1

Hidalgo M., Tomás J., Moranta J., et al. 2009. Intraannual recruitment events of a shelf species around an island system in the NW Mediterranean. Estuar. Coast. Shelf Sci. 83: 227-238. https://doi.org/10.1016/j.ecss.2009.03.037

Ifremer. 2007. ISIS-Fish. Downloaded from http://www.isis-fish. org. accessed 23 August 2018.

Ifremer. 2011. Note sur la création par la CGPM d'une Zone de pêche réglementée dans le golfe du Lion en mars 2009. Accessed 23 August 2018 http://archimer.ifremer.fr/doc/00086/19688/

Irazola M. Lucchetti A., Lleonart J, et al 1996. La Pesca en el siglo XXI. Propuestas para una gestión pesquera en Catalunya. C.C.O.O. Federación del transporte, Barcelona.

Kell L., Fromentin J.-M. 2007. Evaluation of the robustness of maximum sustainable yield based management strategies to variations in carrying capacity or migration pattern of Atlantic bluefin tuna (Thunnus thynnus). Can J. Fish. Aquat. Sci. 64: 837-847.

https://doi.org/10.1139/f07-051

Lleonart, J. 2005. Mediterranean and Black Sea. In: Review of the State of World Marine Fishery Resources. FAO Fish. Techn. Pap. 457: 49-64.

Lleonart J., Salat J. 1992. VIT Programa de Análisis de Pesquerías. Inf. Técn. Sci. Mar. 168-169: 1-116.

Lleonart J., Maynou F., Recasens L., et al. 2003. A bioeconomic model for Mediterranean fisheries, the hake of Catalonia as a case of study. Sci. Mar. 67(Suppl. 1): 337-351. https://doi.org/10.3989/scimar.2003.67s1337

Macher C., Merzéréaud M., Le Grand C., et al. 2010. Réunion du groupe de travail partenarial bio-économique sur la pêcherie de merlu du golfe du Lion: Analyse d'impacts de scénarios, 6 décembre 2010. Sète, Ifremer. 41 pp.

Maynou F. 2014. Coviability analysis of Western Mediterranean fisheries under MSY scenarios for 2020. ICES J. Mar. Sci. 71: 1563-1571.

https://doi.org/10.1093/icesjms/fsu061

Mellon-Duval C., de Pontual H., Métral L., et al. 2010. Growth of European hake (Merluccius merluccius) in the Gulf of Lions based on conventional tagging. ICES J. Mar. Sci. 67: 62-70. https://doi.org/10.1093/icesjms/fsp215

Plagányi E., Punt A.E., Hillary R., et al. 2014. Multispecies fisheries management and conservation: tactical applications using models of intermediate complexity. Fish Fish. 15: 1-22. https://doi.org/10.1111/j.1467-2979.2012.00488.x

Polovina J.J., Ow M.D. 1983. ECOPATH: A user's manual and program listings. NOAA, National Marine Fisheries Service, Southwest Fisheries Center, Honolulu Laboratory.

Recasens L., Lombarte A., Morales-Nin B., et al. 1998. Spatiotemporal variation in the population structure of the European hake in the NW Mediterranean. J. Fish Biol. 53: 387-401. https://doi.org/10.1111/j.1095-8649.1998.tb00988.x

Recasens L., Chiericoni V., Belcari P. 2008. Spawning pattern and batch fecundity of the European hake (Merluccius merluccius
(Linnaeus, 1758)) in the western Mediterranean. Sci. Mar. 72: 721-732.

https://doi.org/10.3989/scimar.2008.72n4721

Scarcella G., Grati F., Raicevich S., et al. 2014. Common sole in the Northern Adriatic Sea: possible spatial management scenarios to rebuild the stock. J. Sea Res. 89: 12-22. https://doi.org/10.1016/j.seares.2014.02.002

Sharp R., Tallis H.T., Ricketts T., et al. (ed.) 2016. InVEST User's Guide. The Natural Capital Project, Stanford University, University of Minnesota, The Nature Conservancy, and World Wildlife Fund. accessed 23 August 2018.

http://data.naturalcapitalproject.org/nightly-build/ invest-users-guide/html/

Smith A. 1994. Management strategy evaluation: The light on the hill. In: Hancock D.A. (ed.), Population dynamics for fisheries management. Australian Society for Fish Biology, Perth, Western Australia, pp. 249-253.

STECF. 2015. Western Mediterranean Multi-Annual Plan. Publ. Off. Europ. Un., Luxembourg.

Tsagarakis K., Palialexis A., Vassilopoulou V. 2014. Mediterranean fishery discards: review of the existing knowledge. ICES J. Mar. Sci. 71: 1-16. https://doi.org/10.1093/icesjms/fst074

Tserpes G., Politou C.-Y., Peristeraki P., et al. 2008. Identification of hake distribution pattern and nursery grounds in the Hellenic seas by means of generalized additive models. Hydrobiologia 612: $125-133$ https://doi.org/10.1007/s10750-008-9486-X

Tudela S. 2004. Ecosystem effects of fishing in the Mediterranean: an analysis of the major threats of fishing gear and practices to biodiversity and marine habitats. Gen. Fish. Counc. Medit. Stud. Rev. 74: 1-44.

Walters C., Christensen V., Pauly D. 1997. Structuring dynamic models of exploited ecosystems from trophic mass-balance assessments. Rev. Fish Biol. Fish. 7: 139-172. https://doi.org/10.1023/A:1018479526149

Walters C., Pauly D., Christensen V. 1999. ECOSPACE: prediction of mesoscale spatial patterns in trophic relationships of exploited ecosystems, with emphasis on the impacts of marine protected areas. Ecosystems 2: 539-554 https://doi.org/10.1007/s100219900101

\section{SUPPLEMENTARY MATERIAL}

The following supplementary material is available through the online version of this article and at the following link: http://scimar.icm.csic.es/scimar/supplm/sm04748esm.pdf

Table S1. - Main characteristics of the fishing grounds.

Table S2. - European hake growth parameters.

Table S3. - Maturity and weight by age of the European hake population.

Table S4. - Fecundity by age of the European hake population.

Table S5. - Fecundity coefficients of the European hake population.

Table S6. - Natural mortality and survivorship by age of the European hake population.

Table S7. - Exploitation fraction by subregion based on fishing effort.

Table S8. - Fishing mortality and vulnerability by age class.

Table S9. - VIT inputs.

Table S10. - InVEST migration tables.

Fig. S1. - Spatial distribution of European hake by depth. A, abundance of ages 3,4 and 5 by depth (commercial fishing data); $\mathrm{B}$, abundance of hake by age (0-3) and depth (MEDITS 2012-2013)

Fig. S2 - Larval dispersal by subregion or fishing ground according to the spatial distribution of age 0 individuals. 


\section{Spatial management of the European hake Merluccius merluccius fishery in the Catalan Mediterranean: Simulation of management alternatives with the InVEST model}

Meryeme Khoukh, Francesc Maynou

Supplementary material 
Table S1. - Main characteristics of the fishing grounds.

\begin{tabular}{|c|c|c|c|c|c|c|}
\hline \multirow{2}{*}{$\mathrm{N}^{\circ}$} & \multicolumn{2}{|c|}{ Average coordinates } & \multirow[b]{2}{*}{ Fishing ground } & \multirow{2}{*}{$\begin{array}{l}\text { Medium } \\
\text { depth (m) }\end{array}$} & \multirow[b]{2}{*}{ Substrate } & \multirow[b]{2}{*}{ Biozone } \\
\hline & MEAN_X & MEAN_Y & & & & \\
\hline 1 & 3747765.466 & 2060699.092 & Malica & 630 & Mud & Bathyal \\
\hline 2 & 3758848.976 & 2124115.892 & L Estartit & 80 & Sandy mud & Deep Circalittoral \\
\hline 3 & 3766404.211 & 2121918.538 & Somera & 141 & Sandy mud & Deep Circalittoral \\
\hline 4 & 3774888.283 & 2117170.902 & El Darrer & 322 & Mud & Deep Circalittoral \\
\hline 5 & 3750886.389 & 2065297.876 & Sot Malica & 434 & Mud & Bathyal \\
\hline 6 & 3751240.214 & 2070771.865 & Barana & 318 & Rock or other hard substrata & Bathyal \\
\hline 7 & 3746611.969 & 2090204.119 & Planassa & 111 & Rock or other hard substrata & Deep Circalittoral \\
\hline 8 & 3746862.581 & 2078600.037 & Fluviana & 154 & Sandy mud & Deep Circalittoral \\
\hline 9 & 3705140.896 & 2075733.035 & Les Quaranta & 80 & Sandy mud & Deep Circalittoral \\
\hline 10 & 3705126.776 & 2081913.395 & Malgrat-Garotes & 64 & Sandy mud & Upper Circalittoral \\
\hline 11 & 3715697.624 & 2070418.857 & Turó-Paneca & 335 & Sandy mud & Deep Circalittoral \\
\hline 12 & 3709985.807 & 2073420.798 & Capets & 129 & Sandy mud & Deep Circalittoral \\
\hline 13 & 3759875.802 & 2110452.369 & CuldeRecElPas & 182 & Rock or other hard substrata & Bathyal \\
\hline 14 & 3715840.815 & 2062544.283 & Paneca & 555 & Mud & Bathyal \\
\hline 15 & 3774149.401 & 2094936.291 & GambaLlevant & 410 & Sandy mud & Deep Circalittoral \\
\hline 16 & 3773044.364 & 2112937.556 & GambaStSebastià & 518 & Mud & Deep Circalittoral \\
\hline 17 & 3767283.137 & 2087065.943 & Bravada dpt & 247 & Sandy mud & Deep Circalittoral \\
\hline 18 & 3760964.679 & 2090116.639 & Bravada dbf & 141 & Mud & Deep Circalittoral \\
\hline 19 & 3773251.715 & 2082138.435 & Abissínia & 627 & Mud & Bathyal \\
\hline 20 & 3770038.54 & 2083686.82 & Putxet & 370 & Sandy mud & Deep Circalittoral \\
\hline 21 & 3760020.721 & 2102446.47 & Vol de fora & 131 & Rock or other hard substrata & Deep Circalittoral \\
\hline 22 & 3755720.707 & 2105442.224 & L'Avió & 99 & Rock or other hard substrata & Deep Circalittoral \\
\hline 23 & 3733147.569 & 2081327.156 & Turó Gros & 108 & Rock or other hard substrata & Deep Circalittoral \\
\hline 24 & 3744849.393 & 2102257.061 & Vol de terra & 75 & Sandy mud & Deep Circalittoral \\
\hline 25 & 3725028.47 & 2081917.482 & Rocassa & 254 & Sandy mud & Deep Circalittoral \\
\hline 26 & 3729898.714 & 2079765.515 & Can Ferrer & 131 & Sand & Upper Circalittoral \\
\hline 27 & 3737612.127 & 2069005.178 & Través & 432 & Muddy sand & Bathyal \\
\hline 28 & 3730104.528 & 2073402.685 & La Creu & 394 & Muddy sand & Bathyal \\
\hline
\end{tabular}

Table S2. - European hake growth parameters.

\begin{tabular}{lccc}
\hline \multicolumn{2}{l}{ Von Bertalanffy growth equation } & \multicolumn{2}{c}{ Size-weight relationship } \\
\hline $\mathrm{L}_{\text {inf }}$ & 110 & $\mathrm{a}$ & 0.0048 \\
$\mathrm{k}$ & 0.178 & $\mathrm{~b}$ & 3.12 \\
$\mathrm{t}_{0}$ & 0 & & \\
\hline
\end{tabular}

Table S3. - Maturity and weight by age of the European hake population.

\begin{tabular}{lccc}
\hline Age & Maturity & Wt $(\mathrm{kg})$ & Wt $(\mathrm{STECF}, 2015)$ \\
\hline 0 & 0 & 0.000 & 0.022 \\
1 & 0.15 & 0.039 & 0.12 \\
2 & 0.82 & 0.261 & 0.4 \\
3 & 0.98 & 0.715 & 0.991 \\
4 & 1 & 1.369 & 1.62 \\
$5+$ & 1 & 5.995 & 2.81 \\
\hline
\end{tabular}

Table S4. - Fecundity by age of the European hake population.

\begin{tabular}{lcc}
\hline Age & Fecundity (Mean) & Source \\
\hline 0 & 3555 & MEDITS \\
1 & 18225 & \\
2 & 77560 & Commercial fishing \\
3 & 169680 & \\
4 & 281438 & \\
5 & 402275 & \\
\hline
\end{tabular}

Table S5. - Fecundity coefficients of the European hake population.

\begin{tabular}{lc}
\hline Age & $\mathrm{N}(\mathrm{t})=$ Fecundity $* \mathrm{e}^{(-0.1193 * 90)}$ \\
\hline 0 & 0.077 \\
1 & 0.396 \\
2 & 1.685 \\
3 & 3.686 \\
4 & 6.115 \\
$5+$ & 8.740 \\
\hline
\end{tabular}

Table S6. - Natural mortality and survivorship by age of the European hake population.

\begin{tabular}{lcc}
\hline Age & M (ProdBiom) & Sa $\left(S a=\mathrm{e}^{-M a t}\right)$ \\
\hline 0 & 1.15 & 0.31663677 \\
1 & 0.65 & 0.52204578 \\
2 & 0.55 & 0.57694981 \\
3 & 0.51 & 0.60049558 \\
4 & 0.48 & 0.61878339 \\
$5+$ & 0.47 & 0.62500227 \\
\hline
\end{tabular}


Table S7. - Exploitation fraction by subregion based on fishing effort.

\begin{tabular}{|c|c|c|c|c|}
\hline Subregion (Code) & Subregion (Name) & Average effort (Boats*days) & $\%$ Effort & Exploitation fraction (Ex) \\
\hline 1 & Malica & 61 & $2 \%$ & 0.136 \\
\hline 2 & L'Estartit & 89 & $3 \%$ & 0.199 \\
\hline$\overline{3}$ & Somera & 42 & $1 \%$ & 0.094 \\
\hline 4 & El Darrer & 49 & $2 \%$ & 0.110 \\
\hline 5 & Sot Malica & 302 & $10 \%$ & 0.676 \\
\hline 6 & Barana & 274 & $9 \%$ & 0.613 \\
\hline 7 & Planassa & 33 & $1 \%$ & 0.074 \\
\hline 8 & Fluviana & 30 & $1 \%$ & 0.067 \\
\hline 9 & Les Quaranta & 42 & $1 \%$ & 0.094 \\
\hline 10 & Malgrat-Garotes & 95 & $3 \%$ & 0.213 \\
\hline 11 & Turó-Paneca & 51 & $2 \%$ & 0.114 \\
\hline 12 & Capets & 69 & $2 \%$ & 0.154 \\
\hline 13 & CuldeRecElPas & 132 & $4 \%$ & 0.295 \\
\hline 14 & Paneca & 19 & $1 \%$ & 0.043 \\
\hline 15 & GambaLlevant & 46 & $2 \%$ & 0.103 \\
\hline 16 & GambaStSebastià & 447 & $15 \%$ & 1.000 \\
\hline 17 & Bravada dpt & 14 & $0 \%$ & 0.031 \\
\hline 18 & Bravada dbf & 29 & $1 \%$ & 0.065 \\
\hline 19 & Abissínia & 146 & $5 \%$ & 0.327 \\
\hline 20 & Putxet & 58 & $2 \%$ & 0.130 \\
\hline 21 & Vol de fora & 53 & $2 \%$ & 0.119 \\
\hline 22 & L'Avió & 119 & $4 \%$ & 0.266 \\
\hline 23 & Turó Gros & 60 & $2 \%$ & 0.134 \\
\hline 24 & Vol de terra & 260 & $9 \%$ & 0.582 \\
\hline 25 & Rocassa & 54 & $2 \%$ & 0.121 \\
\hline 26 & Can Ferrer & 80 & $3 \%$ & 0.179 \\
\hline 27 & Través & 224 & $8 \%$ & 0.501 \\
\hline 28 & La Creu & 94 & $3 \%$ & 0.210 \\
\hline
\end{tabular}

Table S8. - Fishing mortality and vulnerability by age class.

\begin{tabular}{lcc}
\hline Age & F (STECF, 2015) & Vulnerability \\
\hline 0 & 0.119 & 0.0741433 \\
1 & 1.227 & 0.76448598 \\
2 & 1.605 & $\mathbf{1}$ \\
3 & 1.34 & 0.83489097 \\
4 & 0.283 & 0.17632399 \\
$5+$ & 0.283 & 0.17632399 \\
\hline
\end{tabular}

Table S9. - VIT inputs.

\begin{tabular}{lccc}
\hline Age & Frequency (STECF 2015) & Maturity (Data Collection Framework 2003-2012) & Natural mortality (ProdBiom) \\
\hline 0 & 6589000 & 0 & 1.15 \\
1 & 10610000 & 0.15 & 0.65 \\
2 & 1997000 & 0.98 & 0.55 \\
3 & 124000 & 1 & 0.51 \\
4 & 9000 & 1 & 0.48 \\
$5+$ & 3000 & (García-Rodríguez and Esteban 2002 in STECF, 2015) \\
Parameters of Von Bertalanffy growth equation & & \\
\multicolumn{2}{l}{ and } & & \\
Parameters of the length-weight relationship & 0.57 \\
F terminal & $73,725,000$ & \\
Total catch (2015) in weight (g) &
\end{tabular}


Table S10. - InVEST migration tables.

\begin{tabular}{|c|c|c|c|c|c|c|c|c|c|}
\hline $\begin{array}{l}\text { Migration ma } \\
\text { Sink / Source }\end{array}$ & \multicolumn{2}{|r|}{2} & \multicolumn{2}{|c|}{7} & \multicolumn{2}{|l|}{22} & 23 & \multicolumn{2}{|c|}{24} \\
\hline 1 & \multicolumn{2}{|r|}{0} & \multicolumn{2}{|c|}{0} & \multicolumn{2}{|l|}{0} & 0 & \multicolumn{2}{|c|}{0} \\
\hline 2 & \multicolumn{2}{|r|}{0.9828} & \multicolumn{2}{|c|}{0} & \multicolumn{2}{|l|}{0} & 0 & \multicolumn{2}{|c|}{0} \\
\hline 3 & \multicolumn{2}{|r|}{0.0172} & \multicolumn{2}{|c|}{0} & 0.0507 & & 0 & & \\
\hline 4 & & 0 & & & 0 & & 0 & & \\
\hline 5 & & 0 & & & 0 & & 0 & & \\
\hline 6 & & 0 & & & 0 & & 0 & & \\
\hline 7 & & 0 & & & 0 & & 0 & & \\
\hline 8 & & 0 & & & 0 & & 0 & & \\
\hline 9 & & 0 & & & 0 & & 0 & & \\
\hline 10 & & 0 & & & 0 & & 0 & & \\
\hline 11 & & 0 & & & 0 & & 0 & & \\
\hline 12 & & 0 & & & 0 & & 0 & & \\
\hline 13 & & 0 & & & 0 & & 0 & & \\
\hline 14 & & 0 & & & 0 & & 0 & & \\
\hline 15 & & 0 & & & 0 & & 0 & & \\
\hline 16 & & 0 & & & 0 & & 0 & & \\
\hline 17 & & 0 & & & 0 & & 0 & & \\
\hline 18 & & 0 & & & 0 & & 0 & & \\
\hline 19 & & 0 & & & 0 & & 0 & & \\
\hline 20 & & 0 & & & 0 & & 0 & & \\
\hline 21 & & 0 & & & 0 & & 0 & & \\
\hline 22 & & 0 & & & 0.9493 & & 0 & & \\
\hline 23 & & 0 & & & 0 & & 0.6663 & & \\
\hline 24 & & 0 & & & 0 & & 0 & & \\
\hline 25 & & 0 & & & 0 & & 0 & & \\
\hline 26 & & 0 & & & 0 & & 0.3337 & & \\
\hline 27 & & 0 & & & 0 & & 0 & & \\
\hline 28 & & 0 & & & 0 & & 0 & & \\
\hline Migration ma & & & & & & & & & \\
\hline Sink / Source & 2 & 7 & 8 & 10 & 18 & 21 & 22 & 23 & 24 \\
\hline 1 & 0.00 & 0.00 & 0.00 & 0.00 & 0.00 & 0.00 & 0.00 & 0.00 & 0.00 \\
\hline 2 & 0.95 & 0.00 & 0.00 & 0.00 & 0.00 & 0.00 & 0.00 & 0.00 & 0.00 \\
\hline 3 & 0.05 & 0.00 & 0.00 & 0.00 & 0.00 & 0.06 & 0.06 & 0.00 & 0.00 \\
\hline 4 & 0.00 & 0.00 & 0.00 & 0.00 & 0.00 & 0.00 & 0.00 & 0.00 & 0.00 \\
\hline 5 & 0.00 & 0.00 & 0.00 & 0.00 & 0.00 & 0.00 & 0.00 & 0.00 & 0.00 \\
\hline 6 & 0.00 & 0.02 & 0.00 & 0.00 & 0.01 & 0.00 & 0.00 & 0.00 & 0.00 \\
\hline 7 & 0.00 & 0.75 & 0.00 & 0.00 & 0.00 & 0.00 & 0.00 & 0.00 & 0.01 \\
\hline 8 & 0.00 & 0.02 & 0.92 & 0.00 & 0.01 & 0.00 & 0.00 & 0.00 & 0.02 \\
\hline 9 & 0.00 & 0.00 & 0.00 & 0.13 & 0.00 & 0.00 & 0.00 & 0.00 & 0.00 \\
\hline 10 & 0.00 & 0.00 & 0.00 & 0.49 & 0.00 & 0.00 & 0.00 & 0.00 & 0.00 \\
\hline 11 & 0.00 & 0.00 & 0.00 & 0.00 & 0.00 & 0.00 & 0.00 & 0.00 & 0.00 \\
\hline 12 & 0.00 & 0.00 & 0.00 & 0.13 & 0.00 & 0.00 & 0.00 & 0.00 & 0.00 \\
\hline 13 & 0.00 & 0.03 & 0.00 & 0.00 & 0.03 & 0.02 & 0.00 & 0.00 & 0.03 \\
\hline 14 & 0.00 & 0.00 & 0.00 & 0.00 & 0.00 & 0.00 & 0.00 & 0.00 & 0.00 \\
\hline 15 & 0.00 & 0.00 & 0.00 & 0.00 & 0.00 & 0.00 & 0.00 & 0.00 & 0.00 \\
\hline 16 & 0.00 & 0.00 & 0.00 & 0.00 & 0.00 & 0.00 & 0.00 & 0.00 & 0.00 \\
\hline 17 & 0.00 & 0.02 & 0.01 & 0.00 & 0.01 & 0.00 & 0.00 & 0.00 & 0.03 \\
\hline 18 & 0.00 & 0.02 & 0.00 & 0.00 & 0.94 & 0.00 & 0.00 & 0.00 & 0.02 \\
\hline 19 & 0.00 & 0.00 & 0.00 & 0.00 & 0.00 & 0.00 & 0.00 & 0.00 & 0.00 \\
\hline 20 & 0.00 & 0.00 & 0.00 & 0.00 & 0.00 & 0.00 & 0.00 & 0.00 & 0.00 \\
\hline 21 & 0.00 & 0.03 & 0.00 & 0.00 & 0.00 & 0.92 & 0.00 & 0.00 & 0.03 \\
\hline 22 & 0.00 & 0.00 & 0.00 & 0.00 & 0.00 & 0.00 & 0.94 & 0.00 & 0.04 \\
\hline 23 & 0.00 & 0.00 & 0.00 & 0.00 & 0.00 & 0.00 & 0.00 & 0.76 & 0.05 \\
\hline 24 & 0.00 & 0.00 & 0.00 & 0.00 & 0.00 & 0.00 & 0.00 & 0.00 & 0.68 \\
\hline 25 & 0.00 & 0.05 & 0.06 & 0.13 & 0.00 & 0.00 & 0.00 & 0.12 & 0.05 \\
\hline 26 & 0.00 & 0.05 & 0.00 & 0.13 & 0.00 & 0.00 & 0.00 & 0.12 & 0.05 \\
\hline 27 & 0.00 & 0.00 & 0.00 & 0.00 & 0.00 & 0.00 & 0.00 & 0.00 & 0.00 \\
\hline 28 & 0.00 & 0.00 & 0.00 & 0.00 & 0.00 & 0.00 & 0.00 & 0.00 & 0.00 \\
\hline
\end{tabular}


Table S10 (Cont.). - InVEST migration tables.

\begin{tabular}{|c|c|c|c|c|c|c|c|c|c|c|c|c|c|}
\hline \multicolumn{14}{|c|}{ Migration matrix_age 4} \\
\hline 1 & 0.00 & 0.00 & 0.03 & 0.00 & 0.03 & 0.00 & 0.00 & 0.00 & 0.00 & 0.00 & 0.00 & 0.00 & 0.00 \\
\hline 2 & 0.76 & 0.00 & 0.00 & 0.00 & 0.00 & 0.00 & 0.00 & 0.00 & 0.00 & 0.00 & 0.00 & 0.00 & 0.00 \\
\hline 3 & 0.05 & 0.91 & 0.00 & 0.00 & 0.00 & 0.00 & 0.00 & 0.00 & 0.00 & 0.05 & 0.03 & 0.00 & 0.00 \\
\hline 4 & 0.07 & 0.07 & 0.00 & 0.00 & 0.00 & 0.00 & 0.07 & 0.00 & 0.00 & 0.07 & 0.07 & 0.00 & 0.00 \\
\hline 5 & 0.00 & 0.00 & 0.02 & 0.02 & 0.02 & 0.00 & 0.00 & 0.00 & 0.01 & 0.00 & 0.00 & 0.00 & 0.00 \\
\hline 6 & 0.00 & 0.00 & 0.81 & 0.00 & 0.00 & 0.00 & 0.00 & 0.00 & 0.00 & 0.00 & 0.00 & 0.00 & 0.00 \\
\hline 7 & 0.00 & 0.00 & 0.00 & 0.59 & 0.00 & 0.00 & 0.00 & 0.00 & 0.00 & 0.00 & 0.00 & 0.00 & 0.00 \\
\hline 8 & 0.00 & 0.00 & 0.00 & 0.00 & 0.72 & 0.00 & 0.00 & 0.00 & 0.00 & 0.00 & 0.00 & 0.00 & 0.00 \\
\hline 9 & 0.00 & 0.00 & 0.00 & 0.00 & 0.00 & 0.13 & 0.00 & 0.00 & 0.00 & 0.00 & 0.00 & 0.00 & 0.00 \\
\hline 10 & 0.00 & 0.00 & 0.00 & 0.00 & 0.00 & 0.19 & 0.00 & 0.00 & 0.00 & 0.00 & 0.00 & 0.00 & 0.00 \\
\hline 11 & 0.00 & 0.00 & 0.00 & 0.00 & 0.00 & 0.14 & 0.00 & 0.00 & 0.00 & 0.00 & 0.09 & 0.11 & 0.00 \\
\hline 12 & 0.00 & 0.00 & 0.00 & 0.00 & 0.00 & 0.13 & 0.00 & 0.00 & 0.00 & 0.00 & 0.00 & 0.00 & 0.00 \\
\hline 13 & 0.04 & 0.00 & 0.00 & 0.04 & 0.00 & 0.00 & 0.90 & 0.00 & 0.05 & 0.04 & 0.01 & 0.00 & 0.05 \\
\hline 14 & 0.00 & 0.00 & 0.00 & 0.00 & 0.00 & 0.14 & 0.00 & 0.00 & 0.00 & 0.00 & 0.00 & 0.12 & 0.00 \\
\hline 15 & 0.00 & 0.00 & 0.00 & 0.04 & 0.00 & 0.00 & 0.00 & 0.04 & 0.04 & 0.02 & 0.00 & 0.00 & 0.00 \\
\hline 16 & 0.05 & 0.02 & 0.00 & 0.00 & 0.00 & 0.00 & 0.03 & 0.05 & 0.05 & 0.05 & 0.04 & 0.00 & 0.00 \\
\hline 17 & 0.00 & 0.00 & 0.00 & 0.02 & 0.02 & 0.00 & 0.00 & 0.90 & 0.01 & 0.00 & 0.00 & 0.00 & 0.02 \\
\hline 18 & 0.00 & 0.00 & 0.00 & 0.01 & 0.01 & 0.00 & 0.00 & 0.00 & 0.80 & 0.00 & 0.00 & 0.00 & 0.01 \\
\hline 19 & 0.00 & 0.00 & 0.02 & 0.00 & 0.02 & 0.00 & 0.00 & 0.00 & 0.02 & 0.00 & 0.00 & 0.00 & 0.00 \\
\hline 20 & 0.00 & 0.00 & 0.02 & 0.02 & 0.02 & 0.00 & 0.00 & 0.00 & 0.01 & 0.00 & 0.00 & 0.00 & 0.00 \\
\hline 21 & 0.00 & 0.00 & 0.00 & 0.04 & 0.00 & 0.00 & 0.00 & 0.00 & 0.00 & 0.77 & 0.00 & 0.00 & 0.04 \\
\hline 22 & 0.03 & 0.00 & 0.00 & 0.00 & 0.00 & 0.00 & 0.00 & 0.00 & 0.00 & 0.00 & 0.76 & 0.00 & 0.04 \\
\hline 23 & 0.00 & 0.00 & 0.00 & 0.00 & 0.00 & 0.00 & 0.00 & 0.00 & 0.00 & 0.00 & 0.00 & 0.34 & 0.05 \\
\hline 24 & 0.00 & 0.00 & 0.00 & 0.00 & 0.00 & 0.00 & 0.00 & 0.00 & 0.00 & 0.00 & 0.00 & 0.00 & 0.69 \\
\hline 25 & 0.00 & 0.00 & 0.00 & 0.05 & 0.05 & 0.13 & 0.00 & 0.00 & 0.00 & 0.00 & 0.00 & 0.11 & 0.05 \\
\hline 26 & 0.00 & 0.00 & 0.00 & 0.05 & 0.00 & 0.13 & 0.00 & 0.00 & 0.00 & 0.00 & 0.00 & 0.11 & 0.05 \\
\hline 27 & 0.00 & 0.00 & 0.05 & 0.05 & 0.05 & 0.00 & 0.00 & 0.00 & 0.00 & 0.00 & 0.00 & 0.09 & 0.00 \\
\hline 28 & 0.00 & 0.00 & 0.05 & 0.05 & 0.05 & 0.00 & 0.00 & 0.00 & 0.00 & 0.00 & 0.00 & 0.11 & 0.00 \\
\hline
\end{tabular}
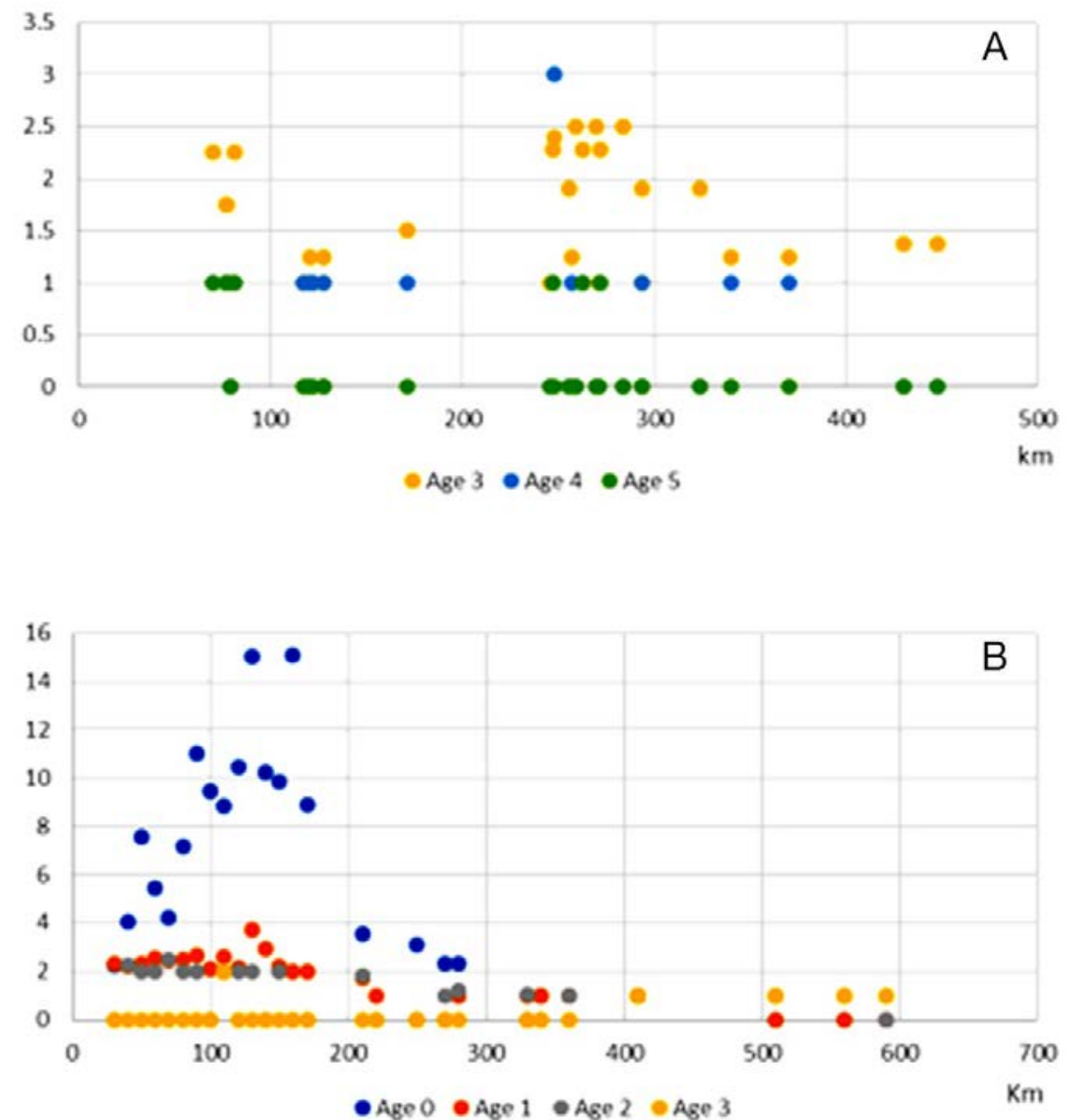

Fig. S1. - Spatial distribution of European hake by depth. A, abundance of ages 3, 4 and 5 by depth (commercial fishing data); B, abundance of hake by age (0-3) and depth (MEDITS 2012-2013). 


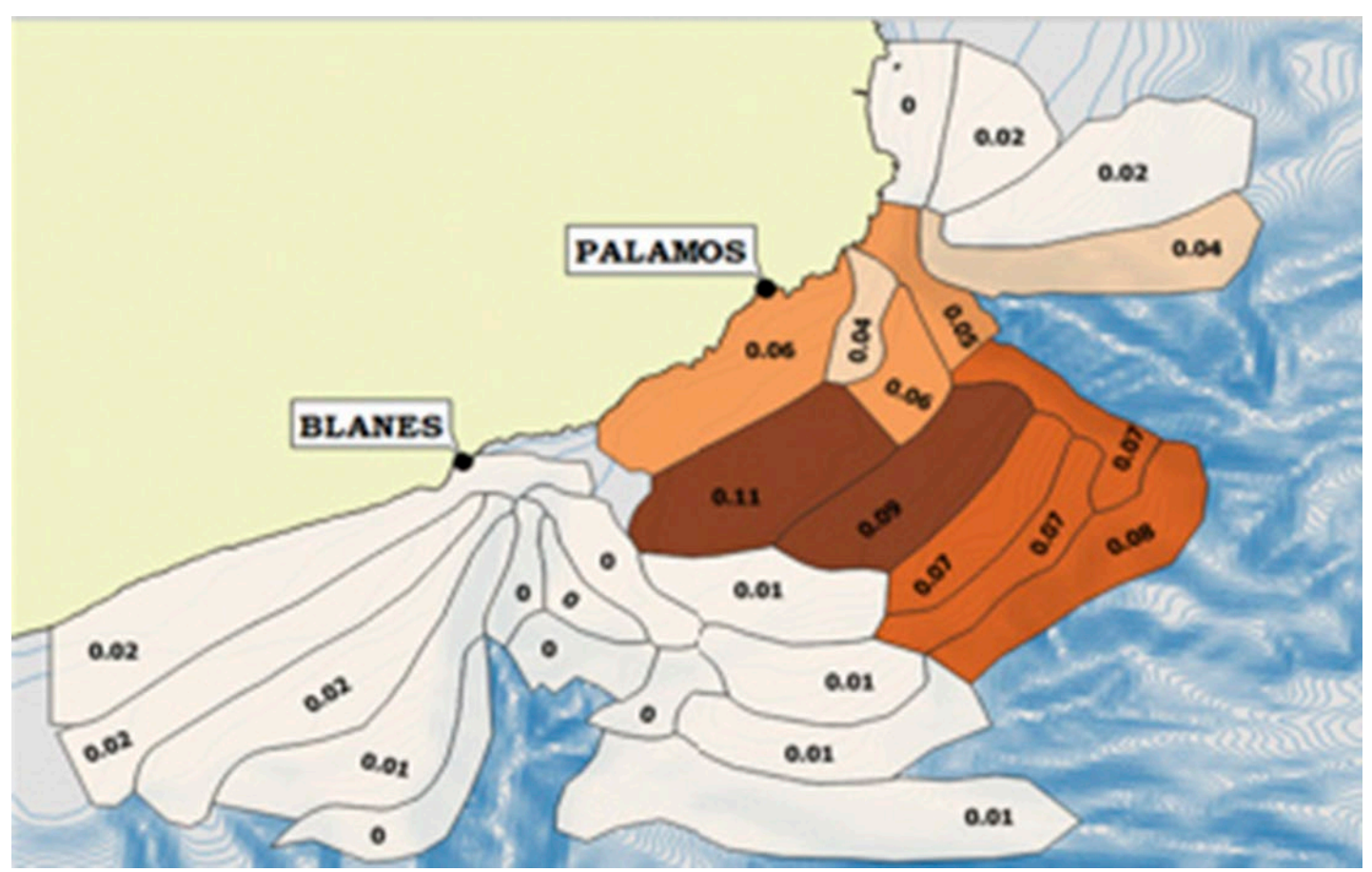

Fig. S2. - Larval dispersal by subregion or fishing ground according to the spatial distribution of age 0 individuals 